\title{
Review of Archaeological Research in Angola
}

\author{
Daniela de Matos $(\mathbb{D} \cdot$ Ana Cristina Martins • João \\ Carlos Senna-Martinez • Inês Pinto • Ana Godinho \\ Coelho - Soraia Santos Ferreira - Luiz Oosterbeek
}

Accepted: 21 December 2020

(C) The Author(s), under exclusive licence to Springer Science+Business Media, LLC part of Springer Nature 2021

\begin{abstract}
This article examines the historical processes that shaped the development of archaeological practice in Angola during the Portuguese colonial period and the aftermath of political independence. Using published works, unpublished reports, and photographic records, we examine the research themes, actors, scholars, and institutions that influenced archaeological research in the country. We also used documents and museum collections in Angola and Portugal to create a GIS database of Angola's archaeological findings. This study highlights the events, personalities, and priorities that motivated earlier investigations, and the geographical distribution of prehistoric sites. We hope this study will be a resource for guiding future archaeological research in Angola.
\end{abstract}

\footnotetext{
D. de Matos $(\bowtie)$

Institute for Archaeological Sciences, Universität Tübingen, Rumelinstr. 23, 72070 Tübingen, Germany

e-mail: daniela.de-matos@uni-tuebingen.de

D. de Matos $\cdot$ L. Oosterbeek

Instituto Terra e Memória, Largo Infante Dom Henrique, Museu De Arte Pré-Histórica, 6120-721 Mação, Portugal

D. de Matos $\cdot$ L. Oosterbeek

Centro de Geociências da Universidade de Coimbra, Rua Sílvio Lima, Universidade de Coimbra - Pólo II, 3030-790 Coimbra, Portugal

D. de Matos $\cdot$ L. Oosterbeek

Instituto Politécnico de Tomar, Quinta do Contador, Estrada da

Serra, 2300-313 Tomar, Portugal
}

Résumé Cet article examine les processus historiques qui ont façonné le développement de la pratique archéologique en Angola pendant la période coloniale portugaise et par la suite de l'indépendance politique. À l'aide d'ouvrages publiés, de rapports non publiés et de documents photographiques, nous examinons les thèmes de recherche, les acteurs, les chercheurs et les institutions qui ont influencé la recherche archéologique dans le pays. Nous avons également utilisé des documents et des collections muséales dans diverses institutions en Angola et au Portugal pour créer une base de données SIG des découvertes archéologiques de l'Angola. Cette étude met en évidence les événements, les personnalités et les priorités qui ont motivé des enquêtes antérieures, et la 
répartition géographique des sites préhistoriques. Nous espérons que cette étude sera une ressource pour guider les futures recherches archéologiques en Angola.

Keywords History of archaeology · Angola · GIS · Colonial collections · Stone Age · Iron Age

\section{Introduction}

Explorer J. C. Tuckey made the earliest known reference to the Angolan archaeological heritage. During his expedition across the Congo river in 1816, he sighted a location called Pedra do Feitiço, a rockshelter with impressive engravings on the walls facing the river. Ricardo Severo, a Portuguese engineer and avocational ethnologist, documented the first prehistoric artifacts in Angola in 1890. He reported a small collection of polished stone tools that were offered to him by an acquaintance. In 1913, José Leite de Vasconcellos, director of the Portuguese National Archaeology Museum, published an article on the prehistoric artifacts from Western and Eastern Africa, being kept at the Geological Services in Lisbon. The article included a bifacial point and handaxes from Angola.

Inevitably, the beginning of archaeology in Angola, as in other parts of Africa, was intertwined with colonial rule. The same actors who served as colonial administrators contributed to the institutional building blocks of scientific research on African prehistory in Angola and Portugal. The independence of Angola in 1975, following about 14 years of war against Portuguese colonial rule, marked a shift in the governance of both countries and consequently a disengagement of the metropolitan research institutions from Angola. A few national and foreign figures tried to continue the existing projects and even establish new areas of investigation, mostly through the National Museum of Archaeology of Angola. However, research efforts declined in the following decades of civil war in the country. The political and social instability, lasting from 1975 through 2002, undermined scientific and academic structures. Much of the country's archaeological heritage was lost during this period of internal conflict and political instability through the plundering of museum collections, illegal trade in antiquities, and the destruction of archaeological sites. For archaeologists, field research was restricted by the proliferation of land mines.
The past decade has witnessed efforts to re-launch archaeological research in Angola. However, these efforts have suffered from lack of a coherent research agenda because of inadequate knowledge of the preceding, colonial-era archaeological research programs. It is challenging to navigate a relatively rich bibliography, mostly published in Portuguese and dispersed across several libraries and archives in Portugal. This review essay serves the purpose of overcoming some aspects of this challenge. It highlights the major discoveries and research questions that guided archaeological field research in Angola before 1975.

\section{Cultures and Geography of Angola}

Before African and European contacts began in the fifteenth century, what is now Angola was inhabited by diverse populations and polities with different traditions, languages, and subsistence strategies (Disney 2009; Thornton 2011). These populations, comprising foragers, herders, and metallurgists, constituted a rich mosaic of cultures and lifeways and were shaped by the diverse landscape and environmental constraints (e.g., Ervedosa 1980). In the southernmost regions, groups of hunter-gatherers shared the landscape with agropastoralists well into the eighteenth century (Almeida 1965). In contrast, more complex agricultural societies had already taken roots in the northernmost regions, close to the rainforest, about 3000 years ago. The latter developed novel social dynamics that led to the emergence of elites and kingdoms during the fourteenth century (Denbow 2014; Vansina 2004). The contacts between these African elites and the Portuguese began the process of reconfiguring the region's social mosaic and its integration into a global trading economy (Heintze 1980). This contact also disrupted several indigenous social structures through the violence associated with the slave trade and the intervention of Portuguese trading missions and political interests in the region (Bender 1978; Boxer 1961; Miller 1988). The consolidation of Portuguese colonialism in the Angola region during the eighteenth and nineteenth centuries paved the way for a longstanding cultural and linguistic connection between Angolan and Portuguese peoples.

In the early nineteenth century, the few European colonial settlements in Angola concentrated along the coast from São Salvador do Congo (M'banza Congo) to Benguela. Even at that time, the European knowledge of 
the interior regions was limited to tales and news from a few explorers. During the European rush for African natural resources in the late nineteenth century, however, nationalist agendas and growing imperialism of postNapoleonic Europe gave rise to a more effective plan of reconnaissance and occupation of the areas between the Atlantic and Indian coasts. Through the initiative of scholars and intellectuals from Portugal, the Lisbon Society of Geography (SGL, Table 1) was founded in 1875. In its early years, the SGL was the most effective Portuguese institution in promoting overseas research and exploration. The development of ethnography, botany, and archaeology in Angola was thus an intrinsic part of the Portuguese colonial plan.

In 1877, explorers Hermenegildo Capelo and Roberto Ivens led an expedition from Luanda to the Congo basin. In 1880, the Ninth International Congress of Anthropology and Prehistoric Archaeology was held in Lisbon, at the Royal Academy of Sciences, established only a few months earlier in 1879. The meeting's attendees emphasized the importance of the ethnographic records gathered among the "current primitives" to understand the archaeological record of European prehistory. Ethnographic research also resonated among Portuguese scholars because of its potential for achieving effective and permanent occupation of the territories disputed with other countries, such as Great Britain, Belgium, and Germany (Lobato 1983; Martins 2010a). In a second expedition, Hermenegildo Capelo and Roberto Ivens again represented the commission on a cross-continental journey which began in Luanda (Angola) and ended in Tete (Mozambique), between 1884 and 1885. Many of the first reports on the cultural heritage, ethnography, and archaeology of central and southern Africa are from this expedition. During this period, the Portuguese University (of Coimbra) began to include anthropological and prehistoric studies in its curriculum (1885). Also, the Portuguese Ethnographic

Table 1 List of acronyms used in the paper

\begin{tabular}{|c|c|}
\hline Acronym & Original (English translation) \\
\hline ESA & Early Stone Age \\
\hline MSA & Middle Stone Age \\
\hline LSA & Late Stone Age \\
\hline EIA & Early Iron Age \\
\hline LIA & Late Iron Age \\
\hline PAA & Pan-African Association \\
\hline INPC & Instituto Nacional do Património Cultural de Angola (National Office for Cultural Heritage) \\
\hline SGL & Sociedade de Geografia de Lisboa (Geographic Society of Lisbon) \\
\hline JMGIC & Junta das Missões Geográficas e Investigação Científica (Board for Geographical Missions and Colonial Research) \\
\hline SGMA & Serviço de Geologia e Minas de Angola (Geological and Mining Services) \\
\hline MAA & Missão de Antropobiologia de Angola (Anthrobiological Mission of Angola) \\
\hline IICA & Instituto de Investigação Científica de Angola (Scientific Research Institute of Angola) \\
\hline JIU & Junta de Investigações do Ultramar (Board for Overseas Research) \\
\hline MEASA & Missão de Estudos Arqueológicos do Sudoeste de Angola (Mission of Archaeological Studies in Southwest Angola) \\
\hline ISCED & Instituto Superior de Ciências da Educação, Angola \\
\hline IPPAR & Instituto Português de Património Arquitectónico, Portugal \\
\hline MNAB & Museu Nacional de Arqueologia de Benguela, Angola (National Archaeology Museum of Benguela) \\
\hline DINAM & Direcção Nacional dos Museus de Angola \\
\hline UISPP & Union Internationale des Sciences Préhistoriques et Protohistoriques \\
\hline LNICT/IICT & Instituto de Investigação Científica Tropical, Portugal (Tropical Research Institute) \\
\hline $\mathrm{AHU}$ & Arquivo Histórico Ultramarino, Portugal (Historical Archive of Overseas) \\
\hline PRISC & Portuguese Research Infrastructure for Scientific Collections \\
\hline LANA & Laboratório Nacional de Antropologia de Angola \\
\hline CICIBA & Centre International des Civilisations Bantu \\
\hline
\end{tabular}


Museum, now known as the National Museum of Archaeology, was created in 1893 in Lisbon. The director of the museum, José Leite de Vasconcellos, intended to gather ethnographic parallels to understand the use and significance of ancestral material culture and effectively connect prehistoric, anthropological, and ethnographic data (Coito et al. 2008).

During the Berlin Conference (1885-1886), tensions rose among European countries competing in Africa's Partition. This compelled the different nations to gather information on the ancient heritage of their colonies, to justify territorial control, and achieve their respective colonial agendas. In Portugal's case, the first geographic expeditions followed this approach, to source the "Pink Map," a document claiming sovereignty over the land between the coast of Angola and the coast of Mozambique, including territories in modern Zambia, Malawi, and Zimbabwe. The Portuguese claim was sustained through historical evidence, mostly from the previous expeditions of Capelo and Ivens, and this invoked the explicit antagonism of the Crown of England, who replied with the "British Ultimatum" in 1890 (Dores et al. 2019). British interests (mainly propagandized by Cecil Rhodes) in these inland territories were driven by the quest for mineral resources and the plan to construct a railway line that would cut across Africa, north to south. Portugal was eventually forced to retreat from some of its southeast African claims to avoid an all-out confrontation with Britain, in the form of trade retaliation, piracy, and warfare.

This situation instigated a severe blow to the Portuguese monarchy and is often cited as a reason for the fall of the Portuguese Crown and the establishment of the Republican regime in 1910. Nevertheless, the project of a "Third Portuguese Overseas Empire," which shifted attention from Brazil to Africa, was kept alive across political regimes (Telo 1994). Territorial occupation for scientific and technological purposes also began to change to a more effective migration of Portuguese colonists to Africa in the early decades of the twentieth century. Most of the settlers were deported felons and political detainees. Poverty and the rise of nationalist ideas in politics after World War I also encouraged many Portuguese families to search for new opportunities in the African colonies. These settler migrations would be crucial to the affirmation of the so-called "nationalist and far-right New State" between 1926 and 1974, an idea built upon propaganda and supported by the press who praised the colonist labor values and imperialist nationalism and glorified Portuguese cultural heritage and the history of past overseas achievements (Martins 2013; Martins and Conde 2010). The colonial project for Africa was one of the main priorities of the Portuguese economic strategy during the following decades of dictatorship, largely with the support of the democratic opposition.

As part of the New State plan, the Portuguese Academy of History (1936) was revived to gather proof of Portugal's undeniable right to its land overseas, in Africa and Asia. The agenda of the New State included a series of commemorations and colloquia, such as the Portuguese Colonial Exhibition held in Porto in 1934. The First National Conference of Colonial Anthropology was held during the last week of the exhibition, with a section devoted to prehistory and archaeology, a practice that mirrored the agendas of the other European empires (Blanchard et al. 2012). The genuine research interest from several scholars, largely influenced by evolutionary theory, easily conflated with the urgency of the colonial project to know more about the indigenous populations in order to make profitable exploration and effective governance of the colonial territory possible (Pereira 2005).

The Board for Geographical Missions and Colonial Research (JMGIC) was founded in 1936, replacing the old Commission of Cartography. The board was managed by the General Agency for the Colonies, the institution responsible for implementing the Scientific Occupation of Portuguese Overseas program that the authoritarian state developed in 1945. During these early years of the New State, the research agenda was driven by the quest to associate ethnographic observations with territorial boundaries and distinct populations. Hence, physical anthropology became an integral part of the colonial anthropologists' research agenda. António Augusto Mendes Corrêa was a widely recognized anthropologist, professor, and politician during this era. He founded the Portuguese Society of Anthropology and Ethnology in 1918. Furthermore, he was a director of the Scientific Research Institute of Anthropology (1912-1923) and the Anthropological Museum (1927) in Porto. He became the president of the JMGIC in 1945, after mentoring some of the first pioneers in anthropological missions. One of these mentees was Joaquim Santos-Júnior, who directed the Mission of Anthropology and Ethnography of Mozambique between 1936 and 1951 (Martins 2010b). The mission defined several goals that were adopted in other 
Portuguese colonies. These included identifying ethnicities, recording bioanthropological data, and collecting artifacts that illustrate cultural traditions and geographical origins. The Mission in Mozambique was influenced by the scientific archaeological research being developed in South Rhodesia (Zimbabwe) and South Africa, where studies of the Stone Age were already being discussed in universities and museums (Martins 2011). All these mission projects fit into the broad colonial scheme of JMGIC, which coordinated the grand efforts to map the ethnology of all Portuguese colonies in Africa-Angola, Guinea-Bissau, and Mozambique (Martins 2014; Martins and Santos 2014, 2015; Mendes Corrêa 1943; Valentim 2016). Emphasis was placed on Angola, as it offered more potential for the exploitation of valuable resources such as diamonds, copper, coal, and ornamental rocks. As this exploitation involved the excavation of several meters of sediment, it also resulted in the location of hundreds of archaeological sites and the subsequent collection of lithic artifacts.

The first major archaeological discoveries from these mining operations occurred in the early 1920 s due to the Geological Mission of Angola's activities, started by Governor-General Norton de Matos in 1921 (Borges and Mouta 1926; Mouta and O'Donnell 1933). Although the Geological and Mining Services (SGMA) in Luanda officially supervised these operations, some of the far interior areas were given prospecting autonomy. This solved a logistical problem: their distance from the capital made accessibility difficult during the wet season. Lundas, one of these remote regions in northeastern Angola, was the center of massive exploration of diamondiferous gravels by the Diamond Company of Angola (Diamang). By 1917, Diamang established an organizational structure for its activities, with an administrative center located in Dundo. This small town emerged due to the need to have a permanent community of workers in the mining operations, comprising Europeans and Africans. As a result, hospitals, schools, libraries, and houses were built and managed by Diamang, providing services to the entire community and resulting in a unique social experiment between colonizers and the colonized.

In 1942, the Cultural Services of Diamang officially established a museum to host the Lunda-Tchokwe ethnographical collection that José Redinha had been assembling since 1936 (Porto 2009). The local population had an important role in the museum by contributing directly to the survey and collections, sourced as gifts from the local communities and the chiefs who, allegedly, considered the museum their "tribal mansion" (Vilhena 1955). Thereafter, the mining operations of Diamang included the collection, study, conservation, and exhibition of archaeological and ethnographic materials as part of the company's social mission and cultural assimilation policy. Others considered this socalled positive social inclusion scenario rather elusive and reflecting a deep problem between non-Africans and Africans. For example, despite the attention paid to the materials of African cultural heritage at Dundo, Africans suffered from segregation inspired, arguably, by British and Belgian colonial policies and an imperialist intellectual tradition in which natives were treated as "just a museum piece" (Freyre 1953). Despite these allegations, the Dundo Museum was one of the leading research institutions in sub-Saharan Africa at the time, and it promoted investigations in the fields of biology, geology, ethnography, and anthropology. It attracted prominent names in these fields of research to Lundas. For example, Diamang supported Jean Janmart, head of the company's Prospecting Brigade, and the prehistorians he invited to Dundo, to discover more about the early Quaternary at Lundas and the "Sangoan Man" (Janmart 1953). Among these scholars were Henri Breuil, Louis Leakey, and John Desmond Clark. The mining of Northern Angola provided a unique opportunity to study Pleistocene and Holocene sediments of the Congo basin and recover archaeological materials buried under thick soil cover and dense vegetation. Most of what is known about the Stone Age of the area resulted from geological explorations and mining operations. The Dundo Museum came to shoulder the double duty of housing the history of the indigenous populations, both recent and ancient, and providing structured organization for research projects on the prehistory and ecology of Lundas. The publication series of the Dundo Museum (Publicações Culturais) produced many of the few scientific studies ever published about this part of the Congo Basin.

Investigations were also promoted in other parts of Angola to understand the diversity of indigenous populations across the territory (Mendes Corrêa 1943). The bioanthropological missions developed by the colonial board were meant to fill this information gap. In 1951, JMGIC was renamed the Board for Overseas Research (Junta de Investigações do Ultramar, JIU). This name change reflected an ideological shift that bent to the structural renewal of the Portuguese dictatorship. 
Through a constitutional amendment, the term "colony" was changed to "overseas province" (Martins and Conde 2010). In the aftermath of World War II, and alongside a new wave of independence movements in several African colonies, the political reforms occurring in Portugal in the early 1950s were driven by the spirit of enforcing a pluri-continental Nation. The reforms also responded to the underlying pressure of the United Nations. Several multidisciplinary research offices were developed in the colonies to work closely with the universities, often importing professors and assistants from Lisbon, Porto, and Coimbra. And, these research institutes in the colonies had their central administrative offices in Portugal. The Scientific Research Institute of Angola (IICA), for example, was created in 1959 to take over field missions, the management of regional museums, and the exchange of academic professionals between Lisbon and Luanda. Several offices were established across the territory to provide laboratory facilities and archives to these scientists. In southern Angola, the Sá da Bandeira Mission (Lubango) of IICA housed departments for botany, geology, pharmacology, mammalian zoology, and ornithology. IICA was also responsible for managing museums such as the Regional Museum of Huíla, created in 1956 to house the exhibition of ethnographic collections gathered by Alberto Machado Cruz (Cruz 1967). All ethnographical and archaeological activities in southern Angola were integrated into the mission of the IICA in Sá da Bandeira, which was responsible for hosting researchers from Luanda and Portugal.

\section{The Role of Archaeology in the Portuguese Scientific Missions in Angola}

The geological mapping and the construction of railroads to the Congo's interior resulted in the first published map of prehistoric stone tools found in Angola by Engineer Fernando Mouta (Mouta 1934a). As head-chief of the Serviço de Geologia e Minas de Angola (Geological and Mining Services, SGMA), he became an avocational anthropologist. His taste for photography resulted in the oldest known collection of pictures about the native populations of Luanda and Malange (Mouta 1934b). F. Mouta was also very active in international circles. He represented Angola at the Geological Society of England's meetings, where debates about the origins of humans were starting to take place. Under his leadership, the SGMA gathered an important repertoire of paleontological and archaeological materials (Mouta 1948a), later published by J. Desmond Clark (1966) in Diamang's Publicações Culturais series. Most of the foreign researchers who landed in Luanda were usually hosted by F. Mouta before they departed for Lundas. When the First Pan-African Congress on Prehistory was held in Nairobi in 1947, F. Mouta, A. do Vale, and J. Janmart formed the Angolan committee. At the conference, their findings were welcomed as an important part of the ongoing discussion on the origins of humankind. The conference also highlighted a need to pursue more fieldwork in the territory as it could be vital to understanding Central and Southern African lithic sequences (Leakey 1952). The international recommendations strongly influenced efforts to discover more Angolan paleontological remains and motivated cooperation between the colonial delegates from Angola and their peers. For this reason, the Portuguese committee invited Louis and Mary Leakey to visit Angola in January-February 1948. F. Mouta first hosted them in Luanda (Mouta 1948b), and then departed to Lundas for a longer collaboration at the Dundo Museum (Leakey 1949).

These international recommendations were well received by the researchers of the colonial board. As a result, JMGIC launched the Anthropobiological Mission of Angola (MAA) in 1948. António de Almeida directed this five-season mission (1948-1955). The mission intended to collect the physiology, language, traditions, and culture of the indigenous populations while mapping Angola's archaeological heritage. In 1950, geologist José Camarate-França was assigned to codirect the MAA's third campaign and focus specifically on the archaeological sites to collect material culture (Fig. 1). J. Camarate-França was also part of the SGMA, the brigade which had already mapped the geology of Angola and provided information on hotspots for ethnographic and stone age sites (Mouta 1938; Mouta and O'Donnell 1933). The MAA covered a total of 45,000 local communities between 1948, and studied 27 local communities between 1948 and 1955. Thousands of pictures and prehistoric materials were collected from more than a hundred sites. These were brought to Portugal, and the mission proposed to finish their study in the following years (Camarate-França and Almeida 1960), under the direction of IICA and the Center for 


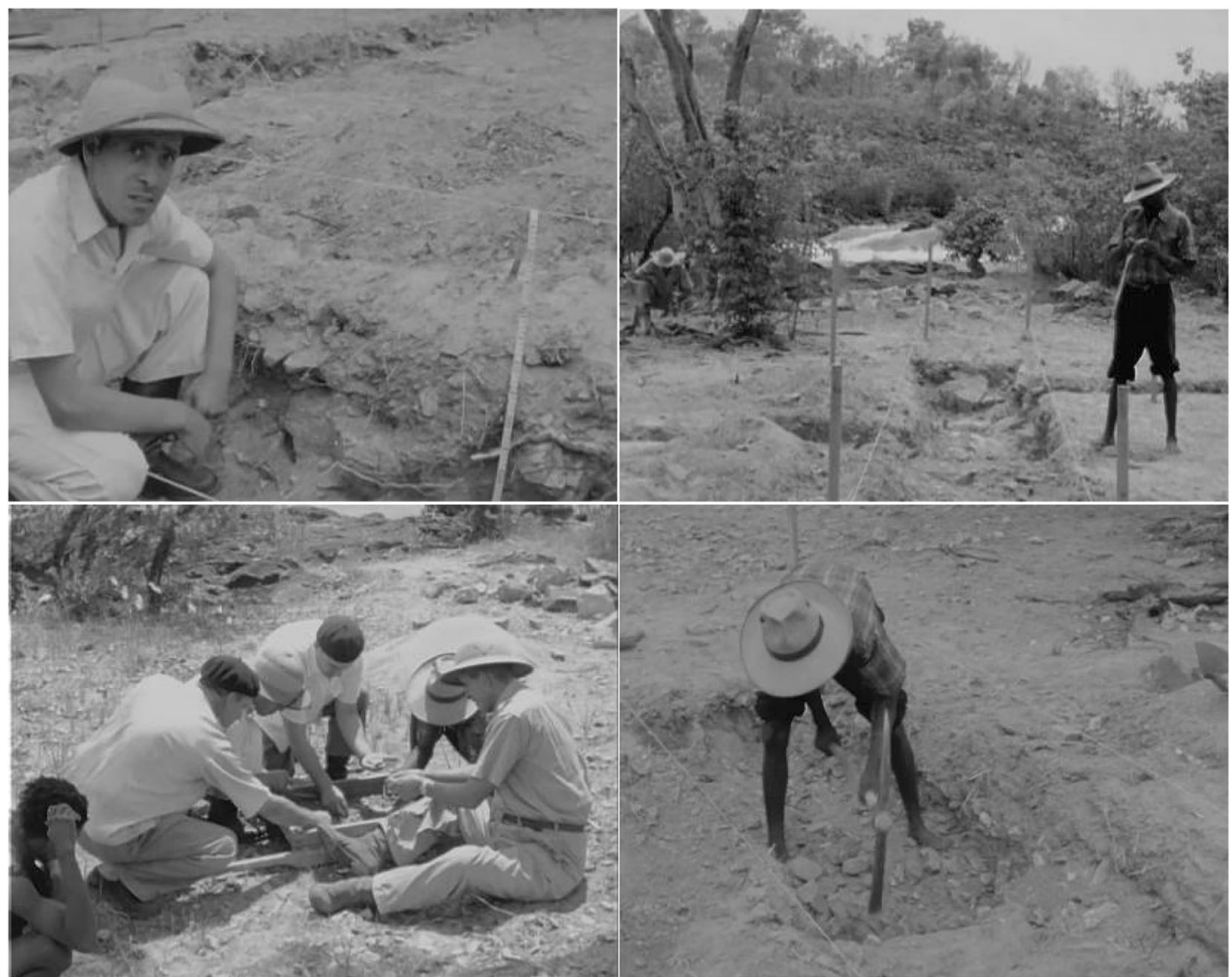

Fig. 1 Photographs from the Anthropobiological Mission, showing Camarate-França and his assistants at Benfica (first row), from the video archive of the Scientific Missions (Arquivo IICT/ULisboa, 1951?)

the Study of Overseas Ethnology, founded in Lisbon in 1955.

However, despite these individual and collective efforts, anthropological and archaeological research had stalled by 1960, perhaps due to the busy schedule of A. Almeida, who frequently joined other expeditions in Timor and was also a member of the Parliament. J. Camarate-França had also drifted away from the Board's activities because he was studying abroad, but he frequently represented the Board at international conferences. Unfortunately, Camarate-França suddenly passed away in 1963, after returning from the Fifth PanAfrican Congress of Prehistory and Quaternary Studies, at Tenerife, in the Canaries. Most of his works (in the form of fieldnotes) were published post-mortem (Camarate-França 1964a, 1964b) by António de Almeida and Henri Breuil in recognition of his scientific role in the Board.

In 1963, another geologist, António Galopim de Carvalho, was proposed to replace Camarate-França.
However, he declined the offer and, instead, accepted a professorship in the Faculty of Sciences at the University of Lisbon. Afterward, a geology student, Miguel Fonseca Ramos, was chosen to complete the Angolan part of the Atlas of African Prehistory (later published by Clark 1967), initially spearheaded by A. Almeida and Camarate-França (Almeida 1964). He was awarded a scholarship to study Prehistoric Archaeology at the University of Paris under the supervision of André LeroiGourhan (Rodrigues 1992). In 1965, M. Ramos was invited to join the Board of Overseas Missions (JIU) and was assigned the task of organizing the missions' records and collections. He directed the division of prehistory and archaeology as an independent center inside JIU. This center inherited all the collections gathered during the previous anthropological missions. Most of these collections required conservation management. As a result, Ramos decided to pursue training at the Royal Museum of Central Africa in Tervuren, Belgium, with Prof. van Noten and another faculty member of the Department of 


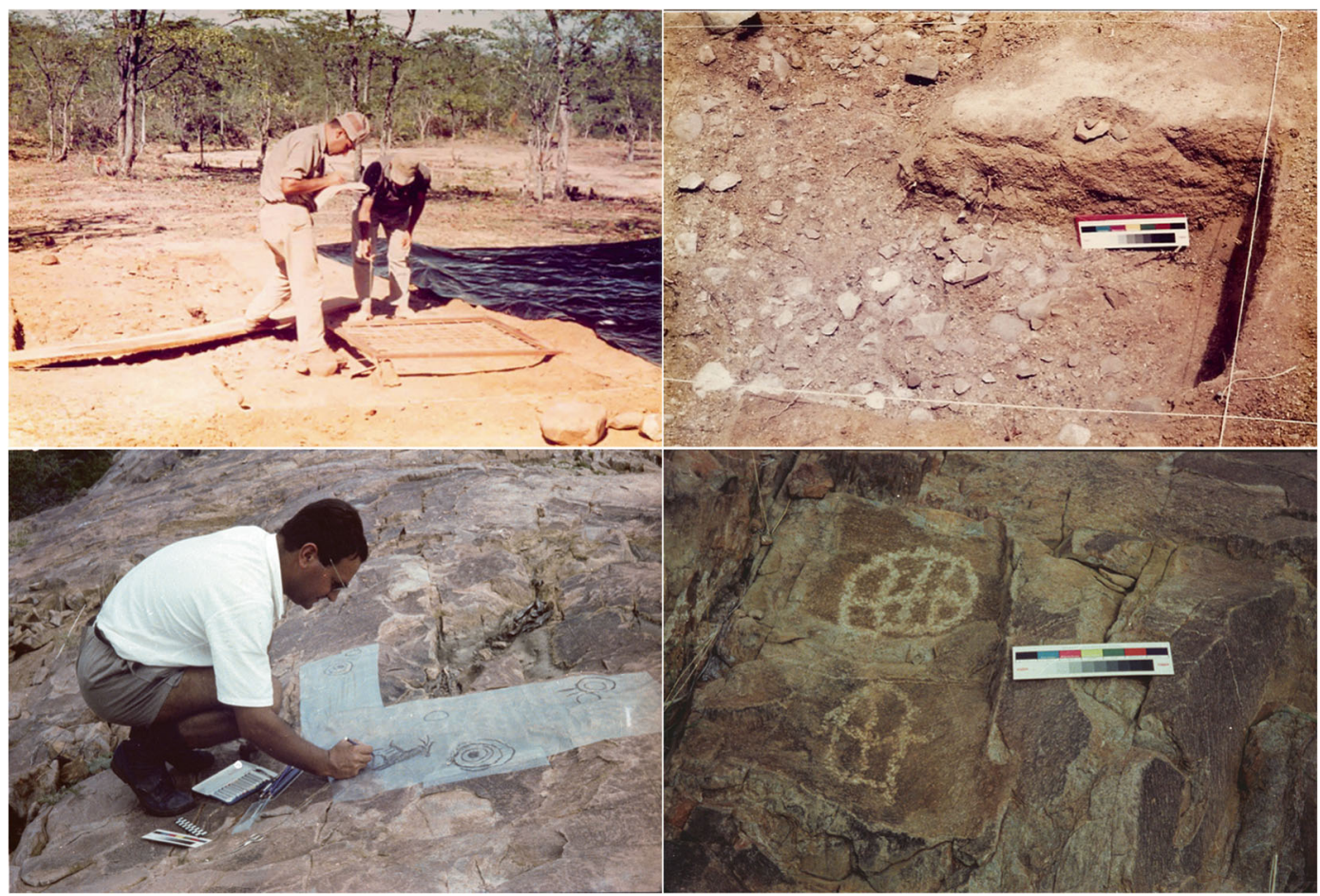

Fig. 2 Photographs from MEASA, showing the work of Miguel Ramos at Capangombe-Velho (first row) and at the site of Monte Negro (second row), from the archive of the Center of Prehistory and Archaeology of the IICT (Arquivo IICT/ULisboa, 1967)

Fig. 3 Lithic artifacts from Capangombe-Santo António (Arquivo IICT/ULisboa, 1967)

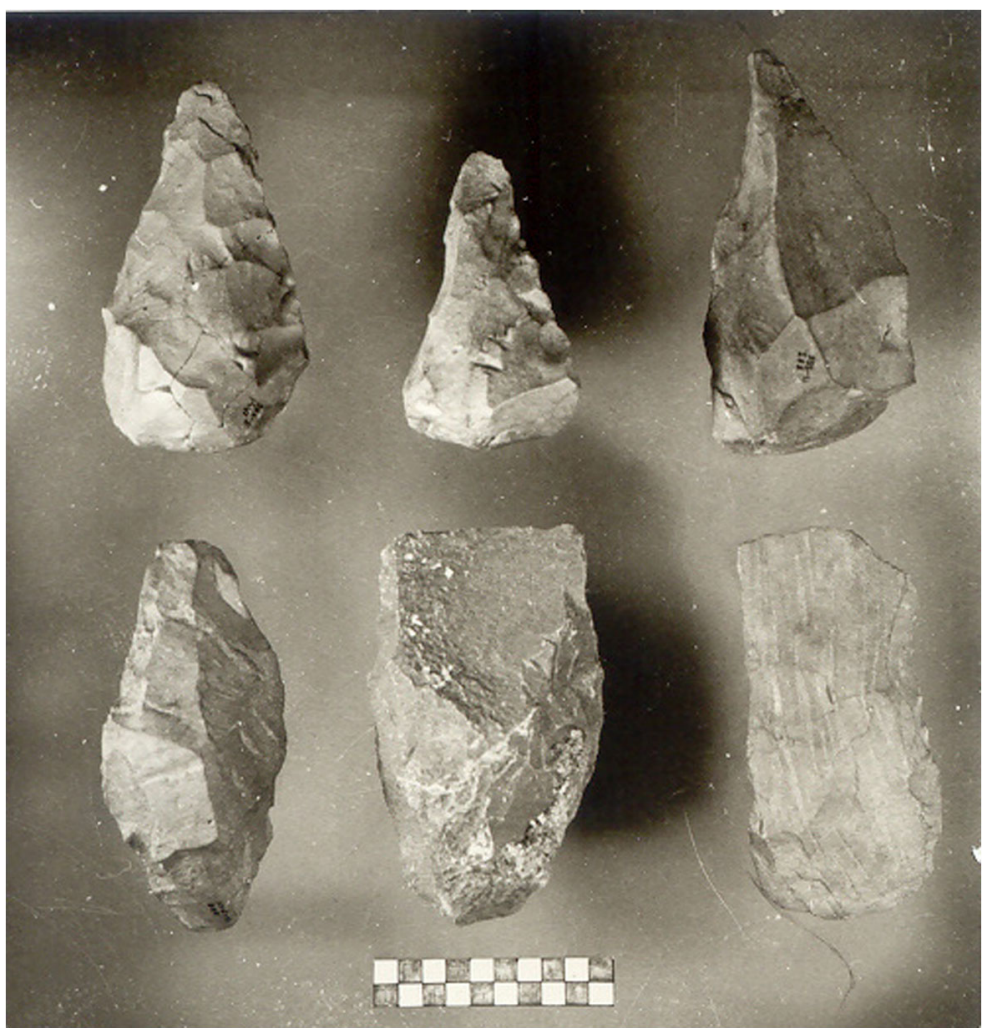


Prehistory at the National Museum of Copenhagen, to learn laboratory techniques in archaeological sciences. When Ramos returned to Lisbon, he was assigned to carry out his first field mission in southwest Angola.

In 1966 and 1967, the geology division of the IICA office in Sá da Bandeira initiated the Mission of Archaeological Studies in Southwest Angola (MEASA) (Ramos 1970). The first goal of MEASA was to locate and map the archaeological sites previously discovered during the MAA projects, using the mission's diaries as a guide (Figs. 2 and 3). The second goal was to survey the region and identify new archaeological contexts. This project led to the discovery of eleven new sites, two of which were excavated: Santo António-Maconge and Capangombe-Santo António (Ramos 1967). Several of the 103,000 artifacts retrieved from the fieldwork were brought to Portugal, in addition to 12,750 pieces from 294 different provenances collected during the MAA project. In 1970, Ramos became the director of the Center of Anthropology, formerly led by A. Almeida. He was soon asked to lead two seasons of the Mission of Archaeological Studies in the Zambezi Valley (1971 and 1972) in Mozambique. The mission involved a survey in the Cahora Bassa Dam's construction area to identify heritage risk zones. This left him little time for his project in Angola.

The network of IICA offices and their collaboration with the University of Luanda guaranteed archaeological and anthropological research and education in Angola throughout the late colonial period, especially 1970-1975. In 1970, classes on archaeology, anthropology, and ethnography were introduced to the School of Arts and Humanities. In 1970, J. Santos-Júnior, former director of Mozambique's anthropological missions, was invited to join the university and manage the archaeology program alongside Carlos Ervedosa. SantosJúnior and Ervedosa teamed up to study Angola's rock art and developed several expeditions with their students (e.g., Ervedosa 1980). Other young scholars, mostly graduate students of the University of Lisbon, were also brought in from Portugal as assistant professors. Vítor Gonçalves was one such junior professor who had a brief stay at the campus in Sá da Bandeira (Lubango) in 1972. After a few months, he was replaced by Vítor Oliveira Jorge, a former collaborator of M. Ramos on the Mission of the Zambezi Valley/Cahora Bassa in 1971. The academic exchange of professors from Lisbon, Porto, and Coimbra was considered necessary to build a strong Portuguese educational system in Angola.
V. Oliveira Jorge was only in Angola for about a year and a half between 1972 and 1974, but his work had a lasting impact. He recruited several students from Sá da Bandeira and developed a series of archaeological investigations across southern Angola. The research team collected assemblages during field trips, mostly in Huíla, Namibe, Cunene, and Huambo districts (Jorge 1974, 1976, 1977). The assemblages have remained to this day in the university building, today known as the School of Educational Sciences (ISCED), in Lubango. Although most collections are from sites previously mapped by the Board of Missions, around 20 new sites were added from different time periods. These research efforts by Oliveira Jorge and his students led to the excavation of at least two sites, the most extensive being the Iron Age site of Ganda. V. Oliveira Jorge published only a few notes on his research in south Angola when he became professor at the University of Porto (Jorge 1975, 1974).

After the Carnations Revolution, which brought the 48-year dictatorship of the New State regime in Portugal to an end on April 25, 1974, thousands of Angolans and Portuguese families fled from the increased political and social tensions originating from the liberation movements. The declaration of Angola's independence in 1975 closed the chapter of Portuguese colonialism in Africa. It also shut the door to the "Plan of Scientific Occupation of the Overseas," which ultimately led to the deactivation of all agencies built around this model. It is unknown how much of Angola's cultural heritage was lost during the following decades of political instability and armed conflict.

\section{The Stone Age Cultures of Angola}

In the years after the first map of prehistoric findings in Angola was published (Mouta 1934a), investigations in the district of Lundas were conducted by a group of officers from the Prospecting Department of Diamang directed by J. Janmart, many of whom were also associated with Dundo Museum. The company motivated them to dedicate a portion of their time to research (Janmart 1946, p. 9). It was a matter of national and international interest to document the peoples and cultures of the Congo Basin, which comprised one of the richest areas in diamonds. Janmart was also part of the circle of investigators into the sedimentary sequence of the Western Congo (Cahen and Lepersonne 1952; Cahen et al. 1959). He became acquainted with the 


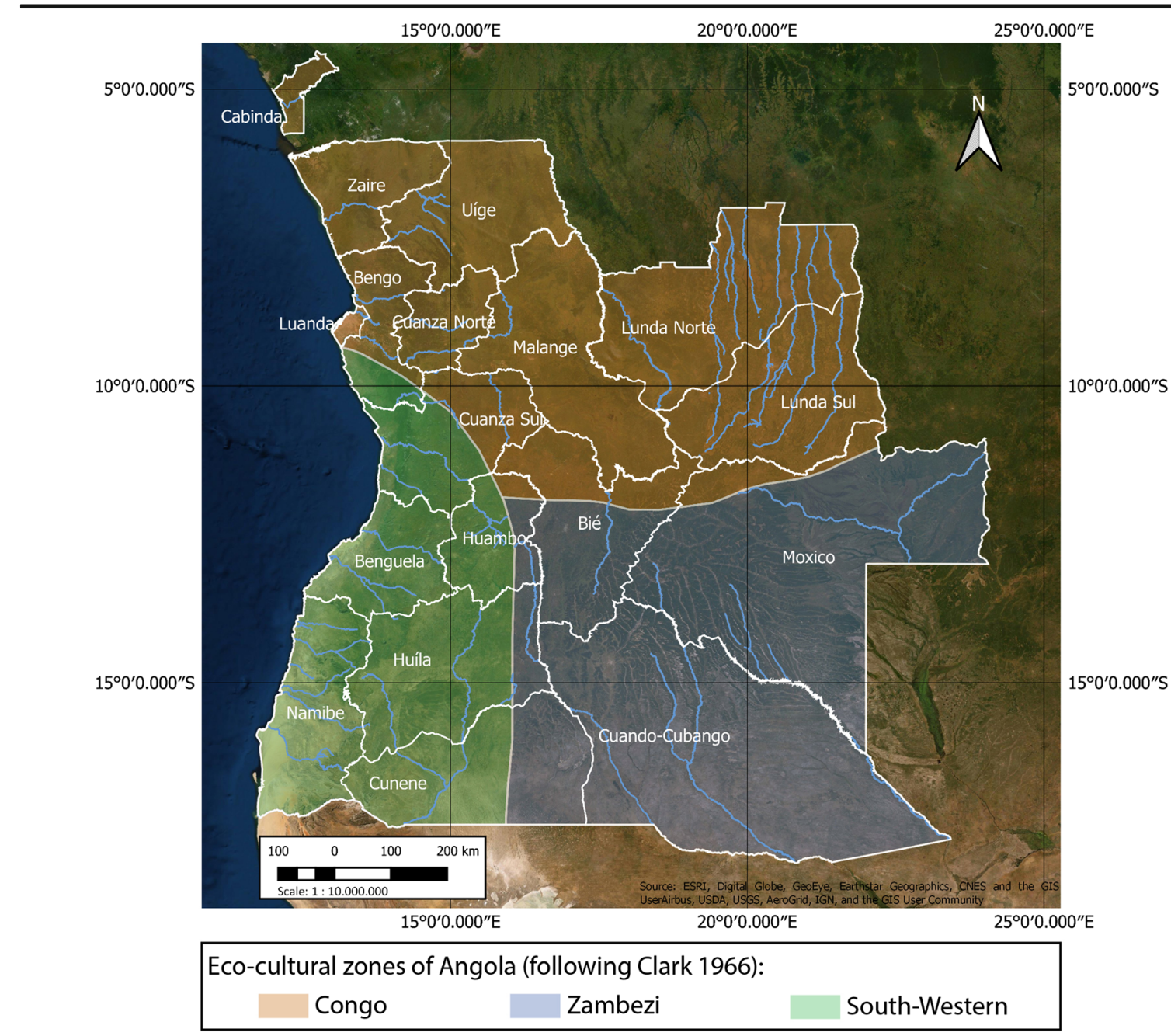

Fig. 4 Geographical boundaries of Angola: administrative divisions (provinces), main rivers, and eco-cultural regions (after Clark 1966)

Africanist scholars who organized the first Pan-African Congress on Prehistory in Nairobi (Leakey 1946). While Mouta presented the new sites discovered in the southwestern region of Angola at that congress, Janmart presented a series of recent discoveries in the Angolan part of the Congo Basin. The latter yielded the potential to refine the sedimentary sequence of the Kalahari Group (also called the Kalahari Sands) and highlighted some geological and cultural features of the Quaternary in Angola.

With these two parallel activities, archaeological research in Angola became polarized between the public colonial board and the private cultural offices of Diamang. In this public-private dynamics, the northeast received more attention through the philanthropy of Diamang, which provided the necessary technical and human resources for a more in-depth characterization of the region's prehistoric record. In contrast, the rest of colonial Angola's archaeology was under the colonial board, which depended on limited public funding, mostly provided by the local administrations, to execute field missions. These conditions resulted in a less systematic study of sites in the south of the country, with just a few sites effectively excavated. As a result, most of the assemblages published were often the result of survey and surface collections.

J. Desmond Clark was the first to attempt a synthesis of Angola's prehistoric cultures (Clark 1966). Clark had replaced Janmart at Lundas in 1959 and later developed extensive studies of the Paleolithic of the region, published by Diamang (Clark 1963, 1968). He also visited the coastal terraces of Benguela. At the Fifth Meeting of the Pan-African Congress of Prehistory and Quaternary Studies in Tenerife (1963), Clark summarized the stone 
age of Angola by integrating his recent findings at Lundas with the previous studies by Janmart, Davies, and the assemblages housed at the museum of SGMA in Luanda. Although Clark often quoted the work of A. Almeida and J. Camarate-França, it is clear that he did not have access to the assemblages of the Anthropobiological Missions in Lisbon. Nevertheless, the Distribution of Prehistoric Culture in Angola (1966) was a seminal work of synthesis for Angola, and it includes a paleoecological model for the region. J. Desmond Clark classified Stone Age Angola into three ecological-cultural zones: Congo, Zambezi, and Southwestern (Fig. 4). Several years later, Ervedosa published "Arqueologia Angolana" (Ervedosa 1980), which remains until today an essential manual on this region's archaeology in Portuguese. Ervedosa adapted the chrono-cultural model of Clark. He kept the stone tool terminology of Kleindienst (1967) for east and southern Africa and added references for fieldwork projects undertaken after 1968.

\section{The Congo Zone}

The Congo zone corresponds to Angola's northern strip, extending from the Atlantic coast in the west to the Cassai (Kasai) river in the east on the border with Zambia. While in the west, the relief is characterized by a series of steps with rivers draining to the ocean, the extensive interior plateau is crossed by a network of subsidiaries of the Cassai-Congo River, running southnorth: Tchicapa, Luachimo, Luana, Chiumbe, and Luembe. More than 80 sites were identified by the Dundo team over twenty years of fieldwork in this region, especially at Lundas. These studies, developed initially by Janmart, defined three types of Quaternary deposits: (1) a series of Redistributed Sands derived from the Pliocene Kalahari Group (Ochre Sands and Clays), covering the interfluves and escarpment edges; (2) alluvial accumulations of pebbles, sands, and clays; and (3) laterites and iron crusts from the weathering of bedrock (Leakey 1949). Janmart mainly focused on gathering evidence on the "Sangoan Man," the presumably local tool maker of the pebble-based industry of core-axes and picks abundantly found in the lower terraces, sometimes with Acheulean features (Janmart 1946). The Sangoan (often also called Kalinian or Tumbian culture) was presumed as an initial stage of the Middle Stone Age (MSA), locally known as the Lupemban culture observed in Central Africa from the
Late Pleistocene (Taylor 2014). The later phase of MSA was characterized by the Tshitolian, a so-called "Epipaleolithic" culture existing before direct evidence of food-production and metallurgy (Ervedosa 1980).

J. Desmond Clark established the sequence for the Stone Age of northeast Angola based on the systematic fieldwork developed under Janmart's directorship. While Early Stone Age (ESA) findings seem to be quite sparse, represented by a few pre-Acheulean elements and Acheulean sites, concentrated on the main river valleys, the MSA and LSA are far more frequent and widespread. Clark considered that more permanent use of the region by human groups had started around the late Acheulean, followed by the development of four cultural stages specific to the Congo basin: Sangoan/ Lower Lupemban, Upper Lupemban, LupemboTshitolian, and Tshitolian cultures. Certain elements seem to be found across the four, namely the presence of core-axes, picks, and choppers, along with lanceolate points. The sequence established by Clark was, admittedly, not based on the introduction of new tool types but rather supported by the metric variability of toolkits and the relative frequencies of artifact classes in each stage (Clark 1963, 1968). Revisions of this work have consistently disregarded the use of the several classifications initially proposed by Janmart (Clark 2001). Angola's Stone Age data is still far too limited because no consistent fieldwork targeting the prehistoric locations has been carried out in the region following Clark's publications. Mining activities have continued at Lundas by other companies, and the Dundo Museum was reopened in 2012, but the focus is now on the ethnography of the Tchokwé. The lithic artifacts from the fieldwork of Janmart and Clark have, for the most part, disappeared.

\section{The Zambezi Zone}

The Stone Age record of the area of the Zambezi and Okavango basin is quite sparse. Findings of the ESA are yet to be identified in the region except for a single Acheulean handaxe found in the confluence of Luconha and Lungué-Bungo Rivers (Ervedosa 1980). MSA assemblages are known from Menongue and the interfluves of the Cunene and Okavango Basins, close to the border with Namibia. These materials were collected by J. Camarate-França, during survey projects either by the Geological Services or by MAA (Almeida and Camarate-França 1965; Camarate-França and Almeida 
1960). In 1952, he identified an archaeological site located on a River Cuebe island, Ilha dos Amores, where a small excavation revealed a three-horizon sequence that yielded a total of 2140 lithic artifacts from two cultural sequences: an in situ "Magosian" industry and an "atypical LSA" assemblage, possibly Wilton. Camarate-França interpreted the site as a knapping "workshop" for composite tools. This hypothesis was based on a techno-typological study of the pieces, showing a blade-bladelet industry with an abundance of cores and knapping debris, as well as unfinished pieces and geometric tools. Another location in the vicinity of Menongue is Galangue, a site with an "undifferentiated MSA" assemblage (Clark 1966), with surface findings that include five polished axes, interpreted as local Neolithic similar to some pieces from western Congo (Jorge 1974).

In the river terraces of Cuengue and Xissói, there are also records of bored stones and lithic tools. Other locations are known further south, close to the border with Namibia, in the interfluves of the Okavango drainage basin. Before his death, Camarate-França presented a paper at the Pan-African Archaeological conference in Tenerife in which he identified three other Magosian locations besides Ilha dos Amores-Dirico, Cuangar, and Mucusso. The site of Mucusso was not described in detail, while Dirico and Cuangar were described by Clark (1966) as "undifferentiated MSA." He suggested that cultural variability became more distinctive in the Late Pleistocene when the MSA of the Zambezi zone seems to be characterized by a Still Bay-Pietersburg tradition, which developed into LSA traditions, firstly the "Magosian" and later a Wilton tradition. Such a pattern would be comparable to Central and Southern African sites (Clark 2001), particularly those between the Namib and the Kalahari deserts. The Stone Age record of the region is the most limited in Angola; no research has been conducted since 1970 .

\section{The Southwest Zone}

Geographically, the southwest zone encompasses regions from the western limit of Angola's central plateau in the east to the lowlands and the desert strip of the Atlantic Coast in the west, including a series of raised beaches that extend from south of Luanda to the Cunene river mouth. Most of the initial fieldwork in this zone, between 1950 and 1953, was part of the MAA program and under the directorship of Camarate-França. Some of the work is also based on the first discoveries recorded by F. Mouta and O'Donnell during the geological mapping of the 1930s and 1940s. The oldest lithic industries in the southwest zone are pre-Acheulean implements, classified by several authors as an evolved Oldowan stage. These are particularly evident in the coastal sites from Benguela to Moçamedes, which include LobitoSul, Baía Farta, and Ponta do Giraúl-Moçamedes. Lobito-Sul in Benguela is a marine deposit ca. $100 \mathrm{~m}$ above sea level (asl) with very weathered implements of Oldowan and Acheulean characteristics. Ponta do Giraúl (Namibe) is a marine deposit ca. $35 \mathrm{~m}$ asl, also with very weathered tools such as flakes and chopping tools. Pre-Acheulean sites are not known beyond the coast, although the Plio-Pleistocene breccias in the Humpata Plateau have yielded abundant fauna (Arambourg and Mouta 1952; Mouta 1953). Until now, there are no records of hominid fossils in these breccias, but there is a good record of the fauna from the late Pliocene to the Holocene in the region, which includes primates, rodents, and equids (Delson et al. 2000; Gilbert et al. 2009; Pickford et al. 1994).

More recent geological evidence from the raised beach deposits at Baía Farta in Benguela has provided the data for establishing a chronology of the ESA sequence at the coast (Corvinus 1983; Giresse 2004; Lebatard et al. 2019). The first site was discovered in 1956 by Mascarenhas Neto, geologist of the Geological Services of Angola. The surface of the platform has variable altitudes ranging from 100 to $150 \mathrm{~m}$. Close to the Dungo river, a seasonal stream exposed a four-layer sequence of Tertiary to Quaternary-aged deposits. The first site originally called "Baía Farta" is currently called Dungo III (person. com. by M.H. Benjamim, MNAB). The excavations of the conglomerate resulted in a rich assemblage of handaxes, bifaces, choppers, scrapers, and other tools in close association with the carcass of a beached whale (Gutierrez et al. 2001, 2010). Further excavations, ongoing since 1992, have been undertaken by MNAB and these have mainly focused on two different areas of the complex: Dungo IV and $\mathrm{V}$. The absolute dating of the conglomerate deposits at Dungo IV, containing a typical Acheulean assemblage, has established that the burial of the underlying artifacts started around 714,000 years ago (Lebatard et al. 2019). This date is important in establishing the lower boundary of the ESA sequence on the Atlantic coast. Nevertheless, a better understanding of the post-depositional phenomena at work on this coastline is necessary to clarify the divergent ages between the different sites (e.g., Gutierrez and 
Benjamim 2019; for a review, see Clist 2019) and validate the behavioral models proposed by the authors (see Chazan and Horwitz 2006).

Lithic assemblages, including handaxes and bifaces, have long been identified at several coastal locations, from Benfica to Cunene (Carvalho 1955; Davies 1962). At Bom-Jesus, located south of Luanda along River Kwanza, Camarate-França identified a five-horizon sequence with Acheulean, Still Bay, and "Magosian" cultures (França 1964). His description of the Acheulean layer indicates the occurrence of "Clactionian" and "Tayac" reduction sequences, as well as the presence of core-scrapers on pebbles.

Our limited understanding of the transition from the Acheulean to the MSA in the Southwest zone remains an unresolved problem. J. D. Clark (1966) offered the first ESA sequence in the region and proposed two different Acheulean phases. He applied the term "First Intermediate" to a group of collections similar to other technocomplexes in East and Southern Africa, such as the Sangoan, Fauresmith, and Stellenbosch. M. Ramos carried out studies on this issue in the Escarpment of Chela area. He was motivated by several assemblages with "transitional traits" found on the slopes of the Chela mountain range, a region of semi-desert and dry bush informally called Serra-Abaixo (Allchin 1964). Many of the assemblages from the area below the escarpment showed reduction sequences typical of technocomplexes like the Fauresmith (Munhino, Carvalhão, Ochinjau, São Nicolau, Camucuio, Maconje, and Moçamedes). Other assemblages (Caitou, Montipa) showed features similar to the "Kalinian"/"Sangoan" artifacts, such as the presence of large picks and cleavers, and to examples found in the "Charaman industry" of Zimbabwe (Cooke 1966). This observation is tentative, as the integrity of the assemblages that define the "Charaman" has been questioned (Volman 1984).

At Lucira, Namibe province, the assemblages presented many of the MSA elements, such as prepared core technology, cores and flakes, and scrapers and small chopping tools used in hafted composites, such as chisels and adze blades. However, there was no presence of points, a classic feature of the MSA of southern Africa. This emphasized the idea of a "First intermediate" cultural stage for MSA in the Southwest zone. During the late Middle Pleistocene's major and phase, the human presence in the region was particularly impressive since the slight decrease of rainfall caused the area to shift to a complete desert landscape. Moreover, the presence of Sangoan tools in the area was particularly intriguing as they are usually interpreted as a woodland-adapted industry (Allchin 1964). The field campaign led by $M$. Ramos in 1966 and 1967 was motivated by the desire to answer these questions about the region's cultural and environmental evolution: if the presence or absence of specific toolkits was independent of the ecological setting and resulted from specific adaptive strategies and subsistence. In his surveys, he discovered over 40 new sites (Ramos 1970).

The excavations by MEASA targeted two locations near the plateau escarpment, below the cliff of Serra da Leba and Chela, about $170 \mathrm{~km}$ from the coast: Maconge-Santo António and CapangombeVelho, located in different sections of the Capangombe river banks, a stream running from the Leba waterfalls at $1800 \mathrm{~m}$ a.s.l. Ramos focused on surveying the Capangombe area more extensively because he believed the region was vital to explaining the idea of an "evolved Acheulean" tradition distributed across the Marginal Mountain Range, and preceding the widespread "undifferentiated MSA" found in the interior plateau, from Huíla to Menongue. Ramos identified two cultural variations of the "evolved Acheulean" tradition: an early stage excavated at Capangombe, the "Capangombian," and a later stage found by Camarate-França at Leba Cave, the "Lebian" (Ramos 1981).

Ramos's first publication on the subject was dedicated to the typology of cleavers collected at SantoAntónio in Namibe. He classified a sample of 196 cleavers based on Tixier's (1957) typological criteria and concluded that $51 \%$ of the cleavers were type II, an old tradition of the Acheulean which probably persisted until later in Angola. However, 16.8\% were not classifiable and could not be included in any of Tixier's classifications. Variations in cleaver forms can be caused by many different factors largely independent from chronology or culturally dictated norms of production (such as lithic raw material quality and availability and size of workable clasts). Although Ramos recognized the impacts of these factors on the specific local variations (Ramos 1970), he nevertheless defined the "evolved Acheulean" as an intermediate stage preceding 
the MSA where "Sangoan" techniques coexisted with the techno-cultural features of Acheulean or Fauresmith traditions (Ramos 1982). Unfortunately, Ramos never completed the study of the Capangombe river terraces, where a much larger number of artifacts were discovered. These terraces yielded evidence of two cultural stages, an "evolved Acheulean" and "undifferentiated MSA" which he intended to compare with the sequence from Acheulean to LSA assemblages discovered by Camarate-França at Leba Cave (Camarate-França 1964; de Matos and Pereira 2020).

Interim reports showed that Ramos conducted sediment analysis on the samples from Leba Cave, Capangombe-Velho, and Capangombe-Santo António, in collaboration with the Soils Department of JIU. He was probably seeking to establish a chronostratigraphic correlation of the sites along the western edge of the escarpment and provide further insights about the climate setting and geological context of the transition from the Acheulean to the MSA (Table 2). Erosional processes seem to have altered the southwestern landscape more intensely during the late Middle Pleistocene and early Late Pleistocene (Ricardo et al. 1981). Seasonal monsoons and flash floods (still frequent events on the plateau) have influenced the depositional regimes. These cause, for instance, high energy remobilization of materials, rapid debris flows, gully and stream deposits. Along with issues of preservation of organic material due to high rates of bioturbation and soil acidity, these are important factors to consider, to understand the evolution of the landscape and site formation processes of open-air sites in the region.

For the most part, the MSA and LSA in the Southwest are characterized by occurrences of undifferentiated assemblages, except for a few finds comparable with the Southern African Still Bay or Pietesburg. The conclusion is based solely on the overview of the published material, still lacking an updated revision of techno-typological aspects of the assemblages available. Among numerous sites of "atypical" attributes, highly specialized toolkits emerge on the coast between the end of the Late Pleistocene and the beginning of Holocene. These "coastal facies," often associated with shell middens, are observed across the Atlantic coast from Cabinda to Ponta das Vacas, and particularly well-preserved at Benfica, Palmeirinhas, Lobito, and Benguela (Clark 1966; Ervedosa 1980) (Fig. 5).

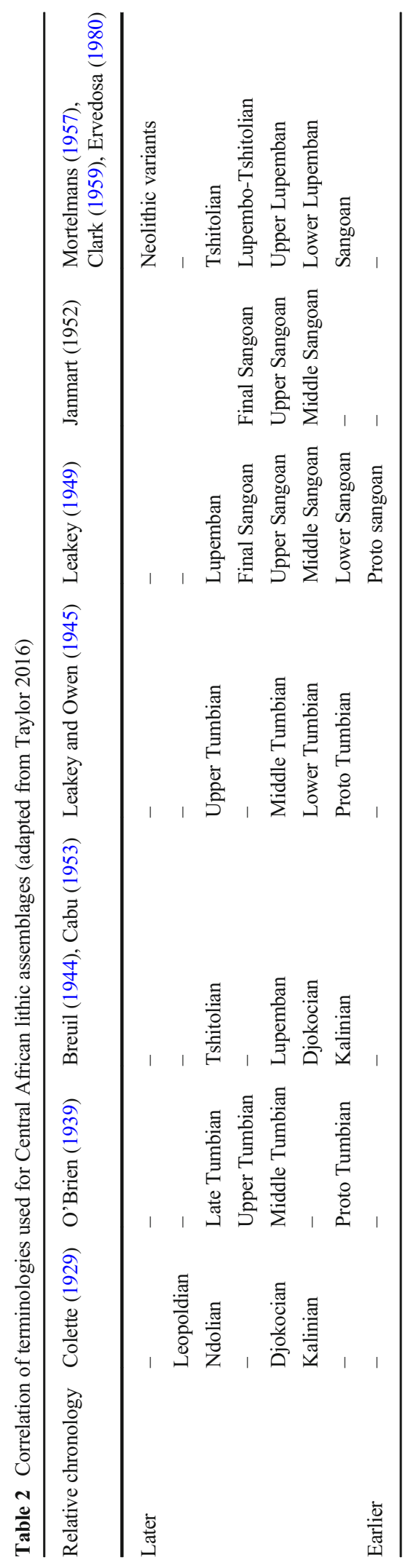




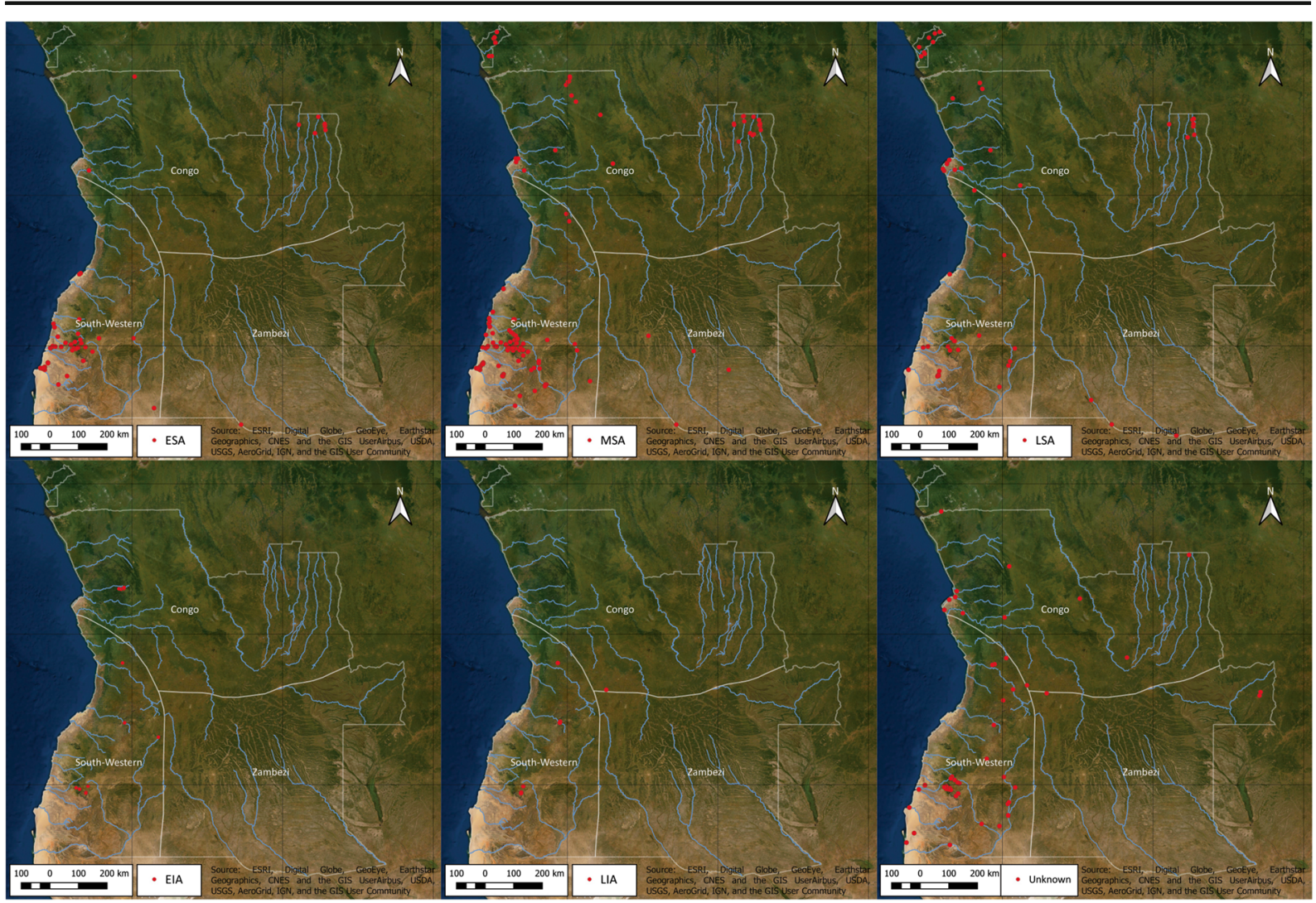

Fig. 5 Distribution of archaeological sites across Angola from different cultural periods based on OSM 1

\section{Regional Variability in Post-Stone Age Cultures of Angola}

The post-Stone Age in Angola is hard to grasp, as very few sites have been effectively studied. This makes it difficult to address the transition in subsistence strategies or technology, from exclusively flaked assemblages to more diverse tool kits frequently associated with what the earlier generation of archaeologists in the region called the "Neolithic." The concept is problematic when applied to the process of expansion of food-production without metallurgy in the rainforest and southern savanna areas, in the western and central parts of Southern Africa (see the discussions in Shaw et al. 1993).

Allegedly, very few food-producing LSA sites are known in Angola. There is one small assemblage of four polished stone axes from the site of S. Salvador do Congo (M'banza Congo), which was offered to the Anthropobiological Mission of Angola in 1950 (Camarate-França 1964c). Although the exact provenance is unknown, it has been hypothesized that these artifacts correlate to the food-producing cultures before the Early Iron Age (EIA) across the Congo basin (de Matos et al. 2013). Some of the northern provinces (Zaire, Uíge, Malange, Lunda Norte, and Lunda Sul), which are part of the southern basin of the Congo River, are within the LSA Ngovo Culture Group's supposed area of distribution (de Maret 1986). Besides this assemblage, there are only two other references of so-called LSA artifacts found in the valley of the Cuanza River and five stone tools discovered in the region of Galangue (Ervedosa 1980, p. 166). Nevertheless, the so-called "Neolithic" label, given by Ervedosa (1980) and other authors, is not contextualized, and the few surface assemblages are insufficient to justify the use of this term. For example, elsewhere in Central Africa, small numbers of polished axes occur in unambiguous LSA hunting/ foraging contexts in southeastern Zambia, as early as 7000 ka (Phillipson 1976). Further work is needed to understand the subsistence strategies between the Later Stone Age and the advent of the Iron Age.

The current evidence seems to support the idea that the adoption of agriculture and animal husbandry across most of Angola occurred only in the Early Iron Age 
(EIA). Although conventional farming features were absent south of the Congo river basin, there is evidence of herding and pottery use by Khoisan groups who were in contact with the EIA farmers and metallurgists (Bon et al. 2012; Sadr 2005, 2014). Nevertheless, the processes of cultural diversification and technological innovation in the Holocene are likely not unilineal across Angola. J. Desmond Clark (1968) suggested that food-producing populations entered Angola from three different areas: from the North, crossing rivers and the coast from Western Africa and the area of Cameroon, towards northwest Angola; from the northeast across the Katanga plateau, along the Zambezi river valley, to the Cassai valley in Lundas; and from the northern Kalahari to southwest Angola. However, these hypotheses are based only on five archaeological sites, museum collections, and a handful of radiocarbon dates (e.g., Ervedosa 1980).

The beginning of EIA in the Lower Congo area has been dated to the first quarter of the first millennium $\mathrm{AD}$ and linked to Bantu expansion's western corridor (Clist et al. 2019b; Denbow 1990; Philipson 2005). Thus, the sites in the northern half of Angola (namely Cabolombo, Dundo, and Quibaxe) and their known pottery industries (Martins 1976; Valdeyron and Domingos 2009) have been correlated to the cultural area encompassing the entire lower Congo basin (Clist et al. 2019a, 2019b) (Fig. 5).

More southerly areas of Angola lack clear evidence of EIA. At the plateau escarpment of Ganda, around $100 \mathrm{~km}$ inland from Benguela, Pedreira da Quitavava was excavated in 1974 by V. Oliveira Jorge (Fig. 6). Coastal sites in Benguela such as Cachama 1 and

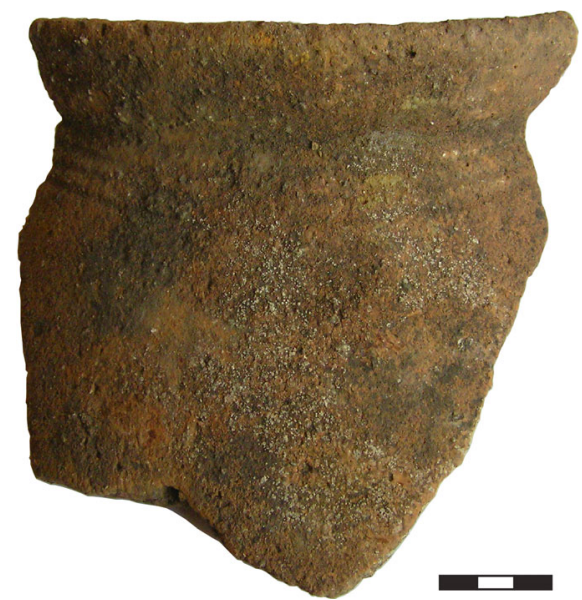

Fig. 6 Early Iron Age decorated pottery fragment from Quitavava, Benguela (by C. Pires, 2004)
Chimalavera at Baía Farta have been classified as "Pastoral Neolithic" (Lanfranchi and Clist 1987). However, across most of the southwestern coast, the sites do not present more than a few pottery fragments and lithic industries which are mostly undifferentiated MSA and LSA toolkits. Similar artifacts are found in most of the shelters with rock art in the region. The exact functions and chronological frameworks of these sites are not known. Neither is it clear if there is any relationship with other painted contexts identified from the coast to the plateau. Consequently, it remains uncertain whether the painters and engravers were hunter-gatherers with pottery ("ceramic LSA"), herders ("pastoral neolithic"), or metallurgists (Iron Age). The inability to place the pottery found in some of these painted rockshelters in cultural and chronological contexts prevents us from choosing the most likely explanation.

\section{Archaeology in Angola After the Independence}

In 1975, academic and heritage offices were restructured. A few museums were kept and integrated into the new organization structure while many were closed down. The Anthropology Museum in Luanda was one of those institutions which survived the reorganization due to the strategic place it occupies in the project of national affirmation. Even during the war, the National Laboratory of Anthropology (LANA) continued to promote a mission of archaeological and ethnographic studies in Soyo. Under the direction of anthropologists Henrique Abranches and Simão Souindoula, the team surveyed the region and excavated the presumed burial site of the Kings of Soyo (Abranches 1991, 1992; Souindoula 1992).

In 1976, the creation of a National Archaeology Museum for Angola was an idea defended by Luís Pais Pinto with the support of key political figures at the time, including Henrique Abranches and Agostinho Neto. The museum was installed in a sixteenth-century historical building where the Customs House of Benguela was previously located. Before the abolition of slavery, this building also served as shelter-prison for thousands of enslaved captives being deported to the Americas. This historical background, imprinted on the museum's walls, reminds visitors of the building's role in the painful past of the region. In 1979, Julião Mateus "Dino Matrosse," Commander of Benguela, led the official opening ceremony. L. Pais Pinto was appointed 
director and curator of the museum. Following the advice of J. Desmond Clark, he focused on restarting archaeological fieldwork in the region. He recruited a few of the new and rising generation of prehistoric archaeologists from Lisbon, among them Luís Raposo, at the time a technician at the National Archaeology Museum of Portugal (later becoming its director), Maria João Coutinho, António Carlos Silva, and Hans Seifener. The fieldwork started in 1983 by revisiting the terraces explored by J. Desmond Clark in the 1960s and other locations excavated by Santos Junior and Carlos Ervedosa in the 1970s. The archaeological team explored the shell middens of Baía Farta in Benguela with a test excavation (Fig. 7). L. Pais Pinto was a devoted leader but left very few published records of his fieldwork projects, which were intermittent and lowbudgeted (Pais Pinto 1988, 1992). He relied mainly on collaboration with international peers, including those from the International Center for Bantu Civilizations (CICIBA) of Libreville, Gabon. In 1988, a committee of CICIBA was invited to design a plan of renovation and expansion of the museum, for which they received funds from the French Ministry of Cooperation in Paris to develop a partnership between France and Angola (Lanfranchi and Clist 1987). Although the committee was mainly composed of French researchers, they invited M. Ramos to join the expedition in 1988. This would be the last time that M. Ramos traveled to the country, as he passed away in 1991 without submitting his doctoral thesis on the Middle Stone Age of Southwest Angola.

Another stream of related research endeavors in Angola following independence was the Angola

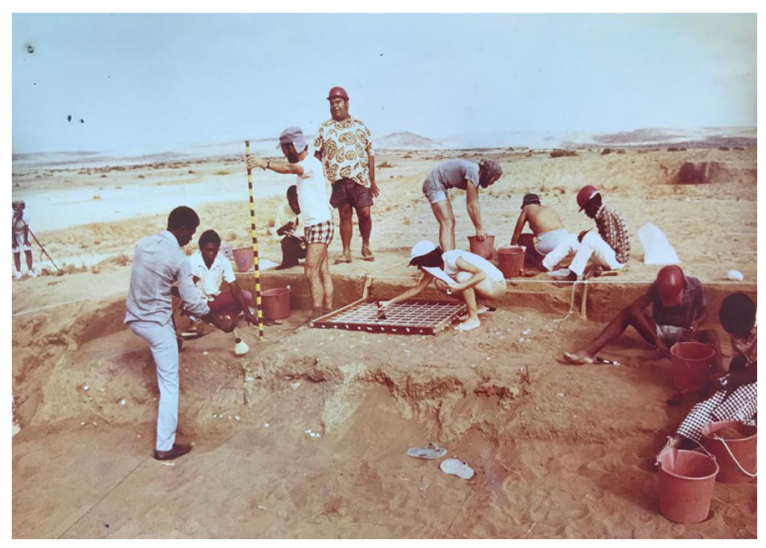

Fig. 7 Excavations at Cachama, showing L. Pais Pinto, the MNAB team, and the team of specialists from Portugal (Arquivo MNAB, 1983)
Palaeontology Expedition (APE) to the Humpata Plateau in July of 1989. It was directed by Martin Pickford of the College of France, in partnership with the Palaeontology Institute in Paris, and with the collaboration of the National Institute of Cultural Heritage of Angola (INPC) and the National Cultural Heritage Institute (IPPAR) of Portugal. This mission was part of a larger paleontological research project founded in 1988 by Martin Pickford and Brigitte Senut, and called "Paleokarst Afrique." The project initially focused on the karst of Botswana, Angola, and Namibia, but later included expeditions in Zambia, Zimbabwe, and South Africa (Pickford et al. 1994). The expedition to southwest Angola was supported by José Ferreira, curator of the Huíla Regional Museum in Lubango. After the independence of Angola in 1975, the museum dropped the exhibition of colonial-era ethnographic materials and focused entirely on south Angola's archaeology. Hence, the expedition of M. Pickford intended to relocate the known fossil sites of Leba and Cangalongue Caves, based on the previous work of Arambourg and Mouta (Arambourg and Mouta 1952). Some of them had been previously mentioned in a report by Robert Mason, based on his brief visit to the Leba quarry in 1975 (Mason 1976). The APE also discovered several new fossil deposits at Cangalongue and Malola. Fossil mammals occur in various fissure infillings, ranging from white travertine to pink sandy breccia and coarse breccia cemented by travertines (Pickford et al. 1990, 1992). Another field season occurred in 1990, focusing on Tchíua, Malola, Cangalongue, and Ufefua where new findings of Middle Pleistocene to Holocene faunal assemblages mainly composed of primates and rodents (Pickford et al. 1994). The field season, however, ended abruptly due to security reasons related to the civil war.

Other collaborations with French partners were fruitful, like the one with Manuel Gutierrez, which started in 1991, and continued systematic research in Angola, with the National Archaeology Museum of Benguela (MNAB). Since Angola became a peaceful state in 2002, collaborations with France, started by Pais Pinto many years before, have contributed to the rise of a new generation of Angolan archaeologists, including museum technical personnel. An important personality in this respect is Maria Piedade de Jesus, who pursued her graduate studies in Paris, focusing on the lithic assemblages from Dungo, and is currently Angola's Secretary of State for Culture. There is also Maria Helena Benjamim, who completed her doctoral studies on the 
pottery from archaeological sites of Benguela (Benjamim 2016), and currently directs the MNAB and the field school at Baía Farta.

Other partnerships, linking the MNAB, the National Institute of Cultural Heritage (INPC), and the National Directorship of Museums (DINAM) to the International Union of Prehistoric and Protohistoric Sciences (UISPP) have led to the development of new collaborative projects. In the framework of an Erasmus Mundus Quaternary and Prehistory Graduate program, involving the Polytechnic Institute of Tomar and the Geosciences Center of Coimbra University, a comprehensive plan for the study of peopling of the Atlantic shores of Africa was developed by L. Oosterbeek and Abdoulaye Camara (from the Institut Fondamental de l'Afrique Noire, in Dakar). The project also created a program for exchanging graduate students between Europe and Africa. As part of this plan, a project entitled "Survey of rock art within an integrated landscape management approach in central Angola" (Oosterbeek et al. 2012) was funded by the Portuguese Foundation for Science and Technology. This project was designed after an initial revision of Angola's rock art bibliography by Cristina Martins (2008). The project focused on the Ebo valley (Kwanza Sul) and related plateau, an area already surveyed decades earlier by Carlos Ervedosa (1980). A total of eighteen painted rockshelters were identified during fieldwork in 2014, showing the occurrence of several layers of paintings, including hunter-gatherers' depictions of Giant Black Antelopes (Palanca Negra Gigante) and a complex ritual context, dated from the eighteenth century AD (Martins 2015). The study of the Ebo Rock art complex became a core part of the overall project (Oosterbeek et al. 2014). Other rock art sites have attracted research attention in Angola, including the Tchitundo-Hulo rock art complex in Namibe (Camarate-França 1953a; Fernandes 2014) and preliminary assessment of the rock art of Sambo (Ganda district, Benguela). These studies, especially that of the Ebo Rock Art project, have combined site contextual analysis with landscape archaeology perspectives and strong attention to heritage issues (Martins and Oosterbeek 2013; Oosterbeek 2013; Rosina et al. 2018), including the production of a scientific documentary (Collado et al. 2015). This multidimensional research strategy, involving archaeologists and cultural authorities in Angola, laid the groundwork for the first nomination of an Angolan site for UNESCO's World Heritage status. UNESCO's international committee recognized the ruins of the Kongo Kingdom capital in M'banza Congo in 2017, and new collaborations are being developed to study this important record (Clist et al. 2018).

Ongoing fieldwork in Angola is mainly based in the southwest. The Baía Farta field school on the Benguela coast, directed by M. H. Benjamim (MNAB), continues the excavations at the Dungo complex, in collaboration with M. Gutierrez (Universite I de Paris). Further inland, at the western edge of the Escarpment of Huíla, the reexcavation of the site Leba Cave has been directed by D. Matos since 2018, focusing on the reassessment of the stratigraphic record of the Middle Stone Age (de Matos 2013, de Matos and Pereira 2020). Currently, the PaleoLeba project has extended to the exploration, survey, and mapping of the karstic systems at the Leba dolomites/Chela series at Humpata, in collaboration with the local communities of Nyaneka-Humbi (de Matos et al. 2020).

Further efforts are being developed within the MNAB to establish a national field school that will overcome the unequal coverage of archaeological research in Angola and promote the development of academic and scientific organizations at the local scale. More systematic research has occurred in the urban centers of Luanda, Benguela, Huambo, and Lubango not only for historical and institutional reasons but also because they have better communication networks, roads, and permanent access to supplies. Poor accessibility and the absence of scientific infrastructure are some of the issues mainly affecting the interior regions. Another challenge for archaeological survey in the hinterlands, especially in the interior plateau (e.g., Bié, Moxico, CuandoCubango, Huambo, and Huíla), is the high chance of encountering landmines due to the previous decades of civil war.

\section{The Tropical Research Institute and the Legacy of Portugal's Scientific Missions}

The dismantling of the colonial structure resulted in the transfer of the Department of Prehistory and Archaeology to the National Scientific Laboratory of Tropical Research (LNICT), founded in 1979 and renamed Tropical Research Institute (IICT) in 1983. In this reorganization, M. Ramos created the Center of Prehistory and Archaeology (Lobato 1983) and obtained an allowance to build the appropriate facilities to study and host the 
biggest reference collection on the Stone Age of Angola, Mozambique, Guinea-Bissau, and Timor. These included a soil science laboratory, photography and map drawing studio, a library, and storage for scientific samples. He had already started a journal in 1978, called "LEBA," to which he invited several international researchers to contribute articles and essays on African prehistory and rock art. He also used the journal to publish his scientific papers on Angola. M. Ramos was very active both in national and international circles of archaeology and geology, lecturing at multiple universities, conferences, and meetings (Rodrigues 1992). M. Ramos never finished his much-expected doctoral dissertation, and his diaries were not found until after his death in 1991. M. Ramos seems to have placed most of his efforts on building up a research center around the collections from Angola. The death of his supervisor, André Leroi-Gourhan, in 1986, could also have posed an obstacle to the completion of his dissertation. Although he had the necessary materials and tools, only a few short articles offered a glimpse of his work in Angola (e.g., Coelho et al. 2015). After his death, the Center of Prehistory and Archaeology was run by his disciples, until its autonomy as an administrative unit ended in 2002, and its operation became part of the Tropical Archive (ACTD-AHU), managed by IICT.

The institute shouldered the conservation and promotion of cultural heritage as part of the agreement among the Portuguese-speaking countries. Some work was done to digitize the collections and inventory and conservation of documents, photographs, films, and artifacts (Casanova et al. 2016; Coelho et al. 2014). One of the goals of IICT was to develop a database that would serve as an online public library for the dissemination of the collections. In 2012, the research project "PROMEMICI - Actors and memories of the 'scientific missions': Archaeology and the Portuguese colonial agenda," directed by A. C. Martins, developed the first efforts to explore the legacy of Portuguese colonial-era research in Africa and elsewhere. As a result, a seminar was launched at the Society of Geography of Lisbon in 2014. An exhibition at the National Museum of Archaeology was also dedicated to the African collections in Portugal (Martins 2014).

After 2012, the African archaeology materials were also included in the GIS mapping of all collections at the IICT. This project involved gathering the geographical record of Angola's archaeological provenances, including all Stone Age and Iron Age sites recorded either by
JIU or locations published later. The goal of this mapping project was to create a complete record of archaeological resources in Angola. Some of the information for this project came from indirect sources like photography, newspaper articles, official reports, and preliminary reports and notes of assistants (IICT, s/d, Pinto and Godinho 20142020, Pais Pinto 1988). A total of 670 locations were mapped (OSM 1), and GIS locations were recovered for more than half of the collection (refer to the online resource, Archaeological Map of Angola). Consistent with the emphasis of the previous research efforts in Angola, Stone Age sites dominate the GIS database. The concentration of discoveries in certain areas of the northeast and Atlantic coast directly reflects the economic interests and colonial agenda that privileged those areas over the interior. Although some coordinates were not possible to establish with accuracy (and thus excluded), the database contains information on the province and municipality of hundreds of archaeological sites (Pinto and Coelho 2015). The institute engaged the services of undergraduate and graduate students who worked on manuscripts, records, and assemblages to retrieve relevant information for the mapping project (Castelo 2015; de Matos 2013; Poloni 2012). These helped to update the provenance of the sites in the database (Figs. 5 and 8). Overall, the inventory provides valuable information on the research background of each site.

Since 2015, the Angolan archaeological heritage in Portugal is managed by the Portuguese Research Infrastructure of Scientific Collections (PRISC). All laboratory facilities of the IICT were closed. Research assets, collections, and personnel were transferred to several colleges and museums of the University of Lisbon. The Archaeology Collections were integrated into the National Museum of Natural History and Science. Currently, the assemblages are curated by the Center of Archaeology of the University of Lisbon (Uniarq)

\section{Final remarks}

The efforts of only a few scholars, administrators, and professionals shaped the history of archaeological research in Angola. The colonial agenda conditioned these efforts, but a strong, genuine, and shared appreciation of the cultural background of Africa also played a 


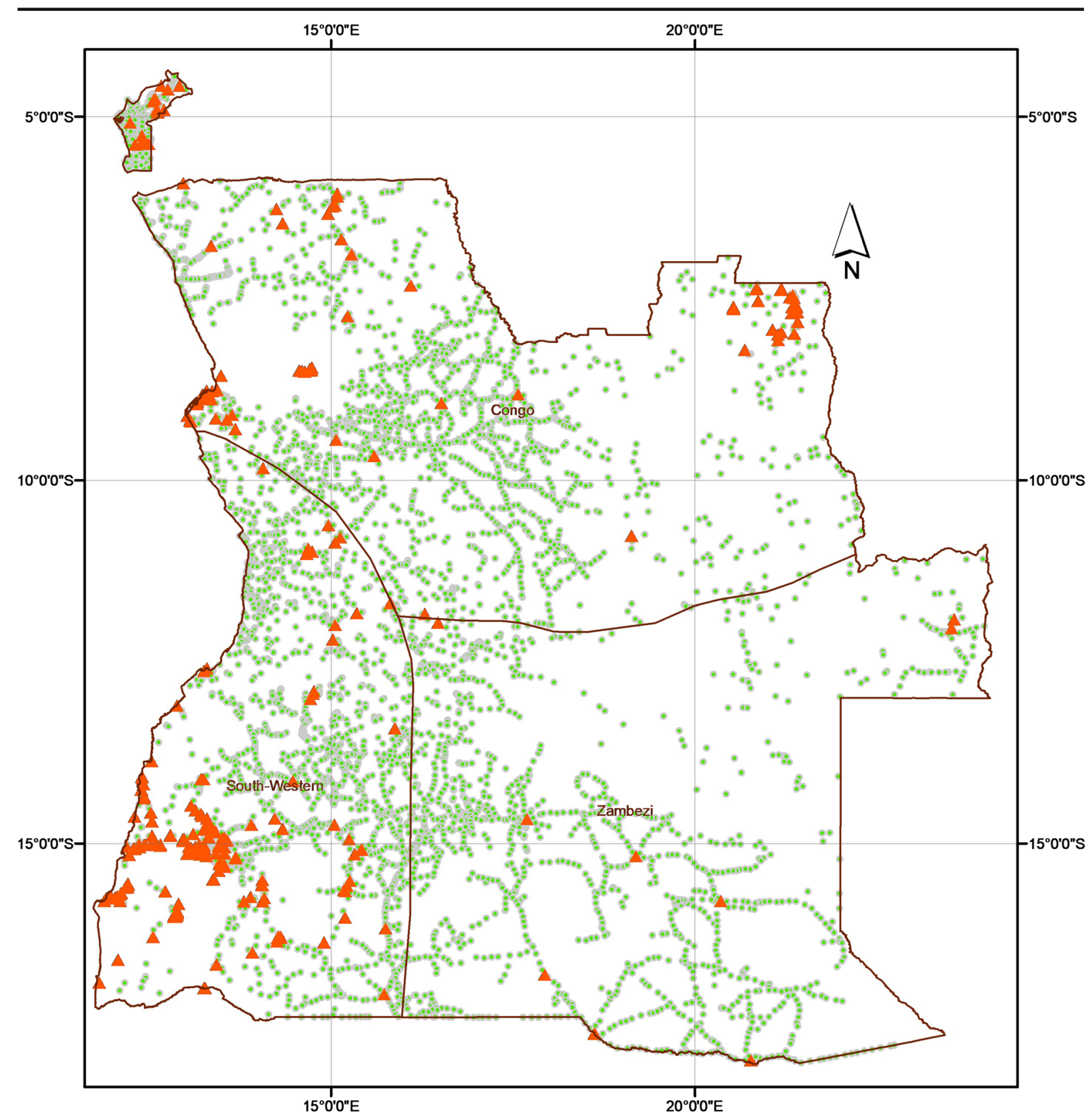

\section{Legend:}

A Archaeological sites

- Soil profile

Eco-Cultural Zones (Clark, 1966)

Fig. 8 Map of archaeological sites and soil profiles provenance georeferenced by the IICT, in Lisbon (by Inês Pinto) 
significant role. The expeditions led by a small group of scholars produced an extensive archaeological record. The archaeological collections at IICT in Lisbon are today the largest and most unique repertoire of reference materials for researchers and students of Angolan prehistory. The artifacts are mostly stone tools but also include paleontological remains, pottery, and metals. It should be noted that most of these materials resulted from preliminary studies by collectors and excavators. The manuscripts, reports, and notes left by those individuals have provided significant information about the toponymy and variability of archaeological sites and the locations of prehistoric heritage. Although sometimes incomplete, the datasets of the assemblages collected before 1975 will be a valuable tool for future students, researchers, and heritage officers in Angola. Considering the checkered history of archaeological research in the former Portuguese colony, it is not surprising that several important records have been lost. These include the field diaries by Portuguese scholars such as Mouta, Camarate-França, and Ramos, who led the country's major share of fieldwork. Moreover, the artifacts from early fieldwork, housed in Luanda's SGMA offices and those from sites excavated by Desmond Clark at Lundas and kept at Dundo Museum, have been lost. These losses have prevented the opportunity to revisit and study these artifacts, using new methods and conceptual frameworks (e.g., Taylor 2016). Consequently, our understanding of early human adaptation and culture in the Congo basin is somewhat limited and is based almost exclusively on the interpretations published by Desmond Clark.

Future directions should aim to overcome the geographical bias resulting from research concentration in the northeast and southwest coastal areas. The virtual absence of archaeology in the Zambezi region of Angola is a crucial issue that needs future attention, given the rich current archaeological data in Africa's southern interior (the Kalahari) (e.g., Burrough 2016, fig. 9.3; Denbow 2014). A refinement of the chronological schemes, based on high-resolution datasets, is still underway and is inevitably dependent on implementing new research strategies and multidisciplinary approaches to old and new records. One of the priorities for the next decades is to establish infrastructure dedicated to the discipline of archaeology and reconnecting universities, museums, and public offices. These efforts are increasingly necessary to preserve the historical and cultural heritage of Angola and the surrounding countries.
Supplementary Information The online version contains supplementary material available at https://doi.org/10.1007/s10437020-09420-8.

Acknowledgments We acknowledge the current curatorship of the IICT collection at the University of Lisbon's National Museum of Natural History and Science and the School of Arts and Humanities: Marta C. Lourenço and João Pedro Cunha-Ribeiro respectively. Special acknowledgments to the students of 1974 in Lubango, especially João e Ana Sá Pinto and Ana Paula Santos, for additional information and helping to track local sources. Special thanks to Maria Helena Benjamim for pictures of L. Pais Pinto in the 1980s, Carlos Pires for the pictures of Quitavava, and Brigitte Senut for the meeting in Paris. We also acknowledge the collaboration of the National Museum of Archaeology in Benguela; the University Agostinho Neto, in Luanda; and the University Mandume Ya Ndemufayo, the Institute of Educational Sciences, and the Regional Museum of Huíla, in Lubango.

Authors' Contributions All authors contributed to the study conception, design, and data collection.

\section{Compliance with ethical standards}

Conflict of interest The authors declare that they have no conflict of interest.

\section{References}

Abranches, H. (1992). Relatório sobre as escavações de Kitala e Kamabangas. LEBA - Estudos de pré-história e Arqueologia, 7, 69-103.

Abranches, H. (1991). Sobre os Basolongo: Arqueologia da tradição oral. Luanda: Fina Petróleos de Angola.

Allchin, B. (1964). A preliminary survey of the sites of the SerraAbaixo, south-west Angola. Memórias da Junta Investigações do Ultramar - Estudos sobre pré-história do Ultramar Português, 50, 81-100.

Almeida, A. (1964). Prefácio. Memórias da Junta Investigações do Ultramar - Estudos sobre pré-história do Ultramar Português, 50, 2-3.

Almeida, A. (1965). The Bushmen and the other Non-Bantu Peoples of Angola. Johannesburg: Witwatersrand University Press for the Institute for the Study of Man in Africa.

Almeida, A., \& Camarate-França, J. (1965). Le Magosien du Sud de L'Angola. In L. D. Cuscoy (Ed.), Actes du V Congres PanAfricain de Prehistoire et de l'Étude du Quaternaire, Santa Cruz de Tenerife, Canarias, 1963 (pp. 107-124). Santa Cruz de Tenerife: Museo Arqueológico.

Archaeological Sites of Angola. (n.d.) An online map database https://ulisboa.maps.arcgis.com/apps/Styler/index. 
html ?appid=d46febd4d 1 fd4 cbfb 5 e 9334 f89663 fae [Accessed December 14, 2020].

Arambourg, A., \& Mouta, F. (1952). Les Grottes et Fentes a ossements du sud de l'Angola. In L. Balout (Ed.), Actes du II Congrès Panafricain de Préhistoire d'Alger, Casablanca 1952 (pp. 301-304). Paris: Arts et Métiers Graphiques Direction des Beaux-Arts du Gouvernement Général de l'Algérie.

Bender, G. (1978). Angola under the Portuguese: The myth and the reality. Berkeley: University of California Press.

Benjamim, M.H. (2016) L'approche ethnoarchéologique de la céramique néolithique du site de Cachama, dans la province de Benguela en Angola. Afrique: Archéologie \& Arts, 12, 97-98.

Blanchard, P., Boëtsch, G., Snoep, N. J., \& Musée du quai Branly (2012). Human zoos: The invention of the savage. Arles: Actes Sud.

Bon, F., Bruxelles, L., Fauvelle-Aymar, F.-X., \& Sadr, K. (2012). Khoekhoe Pastoralists at the junction of historical and archaeological sources. Proposed models for settlement pattern and technological signature of a Neolithic population in southern Africa. P@lethnology, 4, 141-166.

Borges, F., \& Mouta, F. (1926). Congrès géologique international: Communication de la Mission Géologique de l'Angola. Boletim da Agência Geral das Colónias, 2, 30-55.

Boxer, C. R. (1961). Four centuries of Portuguese expansion, 1415-1825: A succinct survey. Johannesburg: Witwatersrand University Press.

Breuil, H. (1944). Le Paléolithique au Congo Belge d'après les recherches de Docteur Cabu. Transactions of the Royal Society of South Africa, 30(2), 143-174.

Burrough, S. (2016). Late Quaternary environmental change and human occupation of the southern African interior. In S. C. Jones \& B. A. Stewart (Eds.), Africa from MIS 6-2: Population dynamics and paleoenvironments (pp. 161174). New York: Springer.

Cabu, F. (1953). Some aspects of the Stone Age in the Belgian Congo. In L. S. B. Leakey (Ed.), Proceedings of the Pan African Congress on Prehistory, Nairobi 1947 (pp. 195201). Oxford: Blackwell.

Cahen, L., \& Lepersonne, J. (1952). Equivalence entre le Système du Kalahari du Congo belge et les Kalahari Beds d'Afrique australe. Mémoires de la Société belge de géologie, de paléontologie et d'hydrologie, 8(4), 1-64.

Cahen, L., Ferrand, J. J., Haarsma, M. J. F., Lepersonne, J., \& Verbeek, T. (1959). Résultats scientifiques des missions $d u$ syndicat pour l'étude géologique et minieère de la Cuvette congolaise et travaux annexes: description du sondage de Samba. Annales du Musee Royal de l'Afrique Central, Tervuren, Belgique - Sci geol, 29.

Camarate-França, J. (1952). Notas e comunicações sobre uma jazida de fácies mesolítica do sul de Angola. Estudos Coloniais, 3(3), 303-305.

Camarate-França, J., (1953a). As gravuras do Tchitundo-hulo (Deserto de Moçâmedes). Mensário Administrativo. Luanda: Oficina Gráfica «O Apostolado».

Camarate-França, J. (1953b). Breve nota sobre uma jazida préhistórica descoberta nos arredores de Luanda. Boletim do Instituto de Angola, 1, 21-28.

Camarate-França, J., \& Almeida, A. (1960). A jazida Magosiense de Vila Serpa Pinto (Angola) Resultados de uma Sondagem.
Memórias da Junta de Investigações do Ultramar - Estudos sobre Pré-História do Ultramar Português, 16(2), 59-68.

Camarate-França, J. (1964a). Nota preliminar sobre uma gruta préhistórica do planalto da Humpata. Memórias da Junta de Investigações do Ultramar - Estudos sobre Pré-História do Ultramar Português, 60, 59-67.

Camarate-França, J. (1964b). Contribuição para o Estudo da Pré Historia da região de S Salvador do Congo. Memórias da Junta de Investigações do Ultramar - Estudos sobre PréHistória do Ultramar Português, 50(2), 69-79.

Camarate-França, J. (1964c). Sobre quatro exemplares, de fácies neolítica, do Norte de Angola. Memórias da Junta de Investigações do Ultramar - Estudos sobre Pré-História do Ultramar Português, 50(2), 49-57.

Carvalho, G. S. (1955). Problemas sobre a sedimentologia das formações detríticas do Baixo Cunene e Cuamato (Angola). Luanda: Serviço de Geologia e Minas.

Casanova, M. C., Coelho, A. G., \& Pinto, I. (2016). Georreferenciando quatro décadas de uma coleção arqueológica de Angola: um projeto para o futuro. Antrope, $5,70-84$.

Castelo, I. (2015). Vestígios arqueológicos - Vale do Zambeze (Moçambique). Master's Thesis: Faculdade de Letras, Universidade de Lisboa, Lisbon.

Chazan, M., \& Horwitz, L. K. (2006). Finding the message in intricacy: The association of lithics and fauna on Lower Paleolithic Multiple Carcass Sites. Journal of Anthropological Archaeology, 25, 436-447.

Clark, J. D. (1959). The prehistory of southern Africa. New York: Plenum Press.

Clark, J. D. (1960). Human ecology during Pleistocene and later times in Africa South of the Sahara. Current Anthropology, 1, 307-324.

Clark, J. D. (1963). Prehistoric cultures of northeast Angola and their significance in tropical Africa. Lisboa. Museu do Dundo-Subsídios para a História, Arqueologia e Etnografia dos Povos da Lunda. Publicações Culturais 62 (2 vol). Diamang, Lisboa.

Clark, J. D. (1966). The distribution of prehistoric culture in Angola. Museu do Dundo-Subsídios para a História, Arqueologia e Etnografia dos Povos da Lunda. Publicações Culturais 73. Diamang, Lisboa.

Clark, J. D. (1968). Further paleo-anthropological studies in Northern Lunda. Museu do Dundo-Subsídios para a História, Arqueologia e Etnografia dos Povos da Lunda. Publicações Culturais 78 (2 vol). Diamang, Lisboa.

Clark, J. D. (1967). Atlas of African prehistory. Chicago: University of Chicago Press.

Clark, J. D. (2001). Variability in primary and secondary technologies of the Later Acheulian in Africa. In S. Milliken \& J. Cook (Eds.), A very remote period indeed (pp. 1-18). Oxford: Oxbow Books.

Clist, B. (2019). Book review of "Recherches archéologiques à Baia Farta (Benguela, Angola)", edited by Manuel Gutierrez and Maria Helena Benjamim. Journal of African Archaeology, 17, 186-189.

Clist, B., de Maret, P., \& Bostoen, K. (2018). Une archéologie des provinces septentrionales du royaume Kongo. Oxford: Archaeopress.

Clist, B., Hubau, W., Tshibamba, J. M., Beeckman, H., \& Bostoen, K. (2019a). The earliest iron-producing 
communities in the Lower Congo region of Central Africa: New insights from the $\mathrm{Bu}$, Kindu and Mantsetsi sites. Azania, 54(2), 1-24.

Clist, B., Kaumba, M., Matonda, I., \& Bostoen, K. (2019b). Kitala ware: A new early Iron Age pottery group from the Lower Congo region in Central Africa. African Archaeological Review, 36(4), 455-477.

Clist, B., \& Lanfranchi, R. (1987). Avant-projet du Musée National d'Archéologie de Benguela, R.P.d'Angola Rapport (pp. 1-32). Paris: CICIBA-Ministère de la Coopération et du Développement / Centre Culturel Français de Libreville.

Clist, B., \& Lanfranchi, R. (1992). Contribution à l'étude de la sédentarisation en République Populaire d'Angola. LEBA Estudos de Pré-história e Arqueologia, 7, 245-267.

Coelho, A. G., Pinto, I., \& Casanova, M. C. (2014). A Coleção Arqueológica do IICT no novo milénio. Antrope, 1, 6-23.

Coelho, A. G., Pinto, I., \& Martins A. C. (2015). Percursos de Miguel Ramos (1932-1991) na arqueologia: síntese e perspectivas". Africana Studia, 24, 145-160.

Coito, L. C., Cardoso, J. L., \& Martins, A. C. (2008). José Leite de Vasconcelos - Fotobiografia. Lisboa: Museu Nacional de Arqueologia/Editorial Verbo.

Colette, J. (1929). Le préhistorique dans le Bas-Congo. Bulletin de la Societé Royale Belge d'Anthropologie et de Préhistoire, $44,41-47$.

Collado, H., Oosterbeek, L., Valongo, P., \& Martins, C. P. (2015). Os abrigos do Ebo. Video (Directed by Enrique Martin). Madrid: Vortize Media.

Cooke, C. K. (1966). Re-appraisal of the industry hitherto named the Proto-Stillbay. Arnoldia (Rhodesia), 2(22), 1-11.

Corvinus, G. (1983). The raised beaches of the west coast of South West Africa/Namibia: An interpretation of their archaeological and palaeontological data. Forschungen zur allgemeinen und vergleichenden Archäologie, 5. München: Verlag G.H. Beck.

Costa, M., Barrulas, P., Dias, L., da Conceição Lopes, M., Barreira, J., Clist, B., Karklins, K., da Piedade de Jesus, M., da Silva Domingos, S., Vandenabeele, P., \& Mirão, J. (2019). Multi-analytical approach to the study of the European glass beads found in the tombs of Kulumbimbi (Mbanza Kongo, Angola). Microchemical Journal, 149, 103990.

Cruz, A. M. (1967). O povo Ovakwambundu. Boletim do Instituto de Investigação Científica de Angola, 4(2), 67-88.

Davies, O. (1962). The raised beaches of Angola and South-west Africa. In G. Mortelmans \& J. Nenquin (Eds.) Actes du IVe Congrès Panafricain de Préhistoire et de l'étude du Quaternaire. Musée Royal de l'Afrique Centrale. Partie administrative. Section I. Géologie, paléontologie générale et climatologie. Section II. Paléontologie humaine. $4^{\circ}$ mayor, VIII. Section III. Pre-et Protohistoire. Annales Série in $-8^{\circ}$, Sciences Humaines 40. (pp. 289-94). Tervuren: Musée Royal de l'Afrique Centrale

Disney, A. (2009). A history of Portugal and the Portuguese Empire: From the beginnings to 1807 (2 vols). Cambridge: Cambridge University Press.

Dores, H. G., Monteiro, J. P., \& Jerónimo, M. B. (2019). 1890: Portugal, Uma Retrospectiva (Vol. 7). Fundação Francisco Manuel dos Santos/ Jornal Público, Lisboa

Delson, E., Terranova, C. J., Jungers, W. L., Sargis, E. J., Jablonski, N. G., \& Dechow, P. C. (2000). Body mass in
Cercopithecidae (Primates, Mammalia): Estimation and scaling in extinct and extant taxa. New York: American Museum of Natural History.

de Maret, P. (1986). The Ngovo Group: An industry with polished stone tools and pottery in Lower Zaire. African Archaeological Review, 4, 103-133.

de Matos, D. (2013). A tecnologia litica da Middle Stone Age da Gruta da Leba. Master's thesis. Faculdade de Ciências Humanas e Sociais da Universidade do Algarve, Faro.

de Matos, D., \& Pereira, T. (2020). Middle Stone Age lithic assemblages from Leba Cave (Southwest Angola). Journal of Archaeological Science: Reports, 32, 102413.

de Matos, D., Oosterbeek, L., Domingos, Z., Miller, C., Conard, N., Neto, M. S., Valongo, P., Fernandes, J., \& Henriques, M. H. (2020). An integrated approach to the construction of cultural landscapes in Southwest Angola: The case of Huíla. In M. Dabas, S. Campana, \& A. Sarris (Eds.), Mapping the past: From sampling sites and landscapes to exploring the 'Archaeological Continuum', Volume 8 Session VIII-1, Proceedings of the 18th UISPP World Congress, Paris (pp. 27-42). Oxford: Archaeopress.

de Matos, D., Senna-Martinez, J. \& Martins, A.C. (2013). Neolithic artefacts from Northern Angola: Revising the data on an ancient collection at IICT. In V. Rodrigues et al (Eds.) Ciência nos Trópicos: olhares sobre o passado, perspectivas de futuro, Arquivo Histórico Ultramarino, Lisboa, 2012. CD-ROM. Lisboa: Instituto de Investigação Científica Tropical.

Denbow, J. (1990). Congo to Kalahari: Data and hypothesis about the political economy of the western stream of the Early Iron Age. African Archaeological Review, 8, 139-176.

Denbow, J. (2014). The archaeology and ethnography of Central Africa. Cambridge: Cambridge University Press.

Ervedosa, C. (1980). Arqueologia Angolana. Lisboa: Edições, 70.

Fernandes, J. B. C. (2014). As Pinturas do Abrigo do TchitunduHulu Mucai. Master's thesis. Instituto Politécnico de Tomar/ Universidade de Trás-os-Montes e Alto Douro, Mação/Vila Real..

Ferreira, S. S. (2019). Os Recintos Amuralhados da Província da Húla. Elementos para um futuro projeto de Investigação. In AULP (Ed.) Património histórico do espaço lusófono: ciência, arte e cultura. Atas do XXVIII Encontro da Associação das Universidades de Lingua Portuguesa, Lubango, 2018 (pp. 545-550). Chisinau: Europress.

Freyre, G. (1953). Um brasileiro em terras portuguesas. Introdução a uma possível luso-tropicologia, acompanhada de conferências e discursos proferidos em Portugal e em terras lusitanas e ex-lusitanas da Ásia, da África e do Atlântico. Rio de Janeiro: Livraria José Olympio.

Gilbert, C. C., McGraw, W. S., \& Delson, E. (2009). Brief communication: Plio-Pleistocene eagle predation on fossil cercopithecids from the Humpata Plateau, southern Angola. American Journal of Physical Anthropology, 139, 421-429.

Giresse, P. (2004). Tropical and Sub-Tropical West Africa Marine and continental changes during the Late Quaternary. Developments in Quaternary Sciences, 10. Elsevier.

Gomes, H., Rosina, P., Martins, A., \& Oosterbeek, L. (2013). Pinturas rupestres - matérias-primas, técnicas e gestão do território. Estudos do Quaternário, 9, 45-55. 
Gutierrez, M., \& Benjamim, M. H. (2019). Recherches archéologiques à Baia Farta (Benguela-Angola) -Pesquisas arqueológicas na Baia Farta (bilingual). Paris: Éditions L'Harmattan.

Gutierrez, M., Guérin, C., Karlin, C., da Jesus, M. P., de Benjamim, M. H., Lebatard, A.-É., Bourlès, D., Braucher, R., \& Leanni, L. (2010). Recherches archéologiques à Dungo (Angola): Un site de charognage de baleine de plus d'un million d'années. Afrique, Archéologie, Arts, 6, 25-47.

Gutierrez, M., Guérin, C., Léna, M., \& Jesus, M. P. (2001). Exploitation d'un grand cétacé au Paléolithique ancien : Le site de Dungo V à Baia Farta (Benguela, Angola). Comptes Rendus de l'Académie des Sciences - Series IIA - Earth and Planetary Science, 332(5), 351-362.

Heintze, B. (1980). Luso-African feudalism in Angola? The vassal treaties of the 16th to the 18th Century. Revista Portuguesa de História, 18, 111-131.

IICT. (n.d.). Center of Prehistory and Archaeology: Records of the archaeological sites of Angola. Instituto de Investigação Científica Tropical: Unpublished Manuscripts. Lisboa.

Janmart, J. (1953). The Kalahari Sands of the Lunda (N.E. Angola): Their earlier redistributions and the Sangoan Culture. Museu do Dundo-Subsídios para a História, Arqueologia e Etnografia dos Povos da Lunda. Publicações Culturais 20. Diamang, Lisboa

Janmart, J. (1946). Les stations paléolitiques de l'Angola NortEst» e «Analyse géologique, climatologique et préhistoric d'un sondage fait en bordure de la rivière Luembe (Angola du Nort-Est). Museu do Dundo-Subsídios para a História, Arqueologia e Etnografia dos Povos da Lunda. Publicações Culturais 1. Diamang, Lisboa

Jorge, S. O. (1976). Vasos Cerâmicos do Abrigo I da Ganda (Angola). Revista de Guimarães, 86, 223-233.

Jorge, V. O. (1977). Alguns elementos para o estudo dos recintos muralhados do Planalto da Humpata. Região da Huíla, Sudoeste de Angola. Revista de Guimarães, 87, 219-246.

Jorge, V. O. (1975). Novas estações arqueológicas do Sudoeste de Angola. Revista de Guimarães, 85, 109-126.

Jorge, V. O. (1974). Breve introdução à pré-história de Angola. Revista de Guimarães, 84, 149-170.

Lanfranchi, R. L., \& Clist, B. (1987). Mission de recherches et de formation en R. P. d'Angola, Octobre 1987. Nsi, 2, 4-8.

Leakey, L. S. (1949). Tentative study of the Pleistocene climatic changes and Stone-Age culture sequence in North-Eastern Angola, Museu do Dundo-Subsídios para a História, Arqueologia e Etnografia dos Povos da Lunda. Publicações Culturais 4. Lisboa: Diamang.

Leakey, L. S. (1946). Pan-African congress on prehistory. Nature, 157, 508.

Leakey, L.S.B., ed. (1952) Proceedings of the Pan-African Congress on Prehistory, Nairobi, 1947. New York: Philosophical Library.

Leakey, L. S. B., \& Owen, W. E. (1945). A contribution to the study of the Tumbian culture in East Africa (Coryndon Memorial Museum Occasional Paper 1). Nairobi: Coryndon Memorial Museum.

Lebatard, A. E., Bourlès, D. L., \& Braucher, R. (2019). Absolute dating of an Early Paleolithic site in Western Africa based on the radioactive decay of in situ-produced ${ }^{10} \mathrm{Be}$ and ${ }^{26} \mathrm{Al}$. Nuclear Instruments and Methods in Physics Research
Section B: Beam Interactions with Materials and Atoms, 456, 169-179.

Lobato, A. (Ed.). (1983). Da Comissão de Cartographia (1883) ao Instituto de Investigação Científica Tropical (1983): 100 anos de História. Lisboa: Instituto de Investigação Científica Tropical.

Martins, A. C. (2014). A Missão Antropológica e Etnológica da Guiné (1946-1947) entre o sagrado e o profano. In A. C. Martins \& A. Santos (Eds.), África reencontrada: o ritual e o sagrado em duas colecções públicas portuguesas - Catálogo da exposição (pp. 21-23). Lisboa: Instituto de Investigação Científica Tropical.

Martins, A. C., \& Santos, A. I. (2014). Ao reencontro do ritual e do sagrado em África. Duas histórias. Uma exposição. In A. C. Martins \& A. Santos (Eds.), África reencontrada: o ritual e o sagrado em duas colecções públicas portuguesas - Catálogo da exposição (pp. 14-15). Lisboa: Instituto de Investigação Científica Tropical.

Martins, A. C., \& Santos, A. I. (2015). A arqueologia portuguesa em solo africano durante o Estado Novo: actores, espaços e projectos. Africana Studia, 24, 129-143.

Martins, A. C. (2013). Viagens, missões e colecções entre agendas políticas e práticas científicas (uma breve reflexão). In CEAUP/Instituto de Investigação Científica Tropical (Eds.), O Colonialismo Português - Novos Rumos Da Historiografia Dos PALOP (pp. 147-162). Famalicão: Edições Húmus.

Martins, A. C. (2011). Archaeology, (post) colonial intents and national identity: Portugal during the first half of the 20th century. In L. Oosterbeek \& C. Fidalgo (Eds.), Postcolonialism and Archaeology: Proceedings of the 15th UISPP World Congress, 2006, Lisboa (pp. 221-237). Oxford: Archaeopress.

Martins, A. C. (2010a). (Re)Conhecer para Ocupar. Ocupar para (re)conhecer. A colonização científica do além-mar. In A. C. Martins \& T. Albino (Eds.), Viagens e Missões Científicas Nos Trópicos 1883-2010 (pp. 26-34). Lisboa: Instituto de Investigação Científica Tropical.

Martins, A. C. (2010b). A arqueologia nas missões científicas: ad initium. In A. C. Martins \& T. Albino (Eds.), Viagens e Missões Científicas Nos Trópicos 1883-2010 (pp. 98-105). Lisboa: Instituto de Investigação Científica Tropical.

Martins, A. C., \& Conde, P. (2010). O Século das Missões. A Ocupação Científica do Ultramar Português sob o olhar da Imprensa. In A. C. Martins \& T. Albino (Eds.), Viagens e Missões Científicas Nos Trópicos 1883-2010 (pp. 39-44). Lisboa: Instituto de Investigação Científica Tropical.

Martins, C. P. (2008). Arte rupestre de Angola - um contributo para o seu estudo numa abordagem à arqueologia do território. Master's Thesis. Instituto Politécnico de Tomar/ Universidade de Trás-os-Montes e Alto Douro, Mação/Vila Real.

Martins, C. P. (2015). Ndalambiri e a arte rupestre do Ebo, Kwanza Sul, Angola: Tempo, espaço e gentes numa paisagem cultural. $\mathrm{PhD}$ dissertation. Instituto Politécnico de Tomar/Universidade de Trás-os-Montes e Alto Douro, Mação/Vila Real.

Martins, C. P. \& Oosterbeek, L. (2013). Projecto Ebo: Arqueologia e património como factores de sustentabilidade e desenvolvimento local. Antrope, 0, 303-313. 
Martins, R. S. (1976). A estação arqueológica da antiga Banza Quibaxe: Dembos - Angola. Contribuições para o Estudo da Antropologia Portuguesa, 9(4) http://hdl.handle.net/10316.2 135248. Acessed 6 Dec 2020

Mason, R. (1976). Exploration archaeology of the Kaokoveld and southern Angola. Annals. South African Museum, 71, 215224.

Mendes Corrêa, A. (1943). As Raças do império. Porto: Portucalense Editora.

Miller, J. C. (1988). Way of death: Merchant capitalism and the Angola slave trade, 1730-1830. Madison: University of Wisconsin Press.

Mortelmans, G. (1957). La préhistoire du Congo Belge. Revue de l'Université de Bruxelles 9e année, 2-3, 119-71.

Mouta, F. (1934a). Contribuição para o estudo da pré-história angolense: distrito de Malange. Comunicações dos Serviços Geológicos de Portugal, 19, 12.

Mouta, F. (1934b). Etnografia Angola: Subsidios. Lisboa: Litografia Nacional.

Mouta, F. (1938). Notice géologique sur l'Angola: Afrique Occidentale Portugaise. Comunicações dos Serviços Geológicos de Portugal, XX, 19-37

Mouta, F. (1948a). Relatório sobre os trabalhos e colecção existentes no Museu dos Serviços e que se referem à PréHistória da Colónia de Angola. Unpublished report from SGMA, Serviços de Geologia e Minas da Colónia de Angola, Luanda (IICT Archive)

Mouta, F. (1948b). Relatório da visita do arqueólogo abade de Breuil a Luanda e seus arredores. Unpublished report from SGMA - Serviços de Geologia e Minas da Colónia de Angola, Luanda (IICT Archive).

Mouta, F. (1953). Possibilidade de existência de Pré-Hominideos no sul de Angola (Leba, Humpata). Anais do Instituto de Medicina Tropical, 10, 2906-2911.

Mouta, F., \& O'Donnell, H. (1933). Carte géologique de I'Angola (1/2000000). Notice explicative. Lisboa: Ministério das Colónias.

O'Brien, T. P. (1939). The prehistory of the Uganda Protectorate. Cambridge: Cambridge University Press.

Oosterbeek, L. (2013). Arqueologia da paisagem em Angola: das materialidades às dinâmicas territoriais. Africana Studia, 20, $11-22$.

Oosterbeek, L., Camara, A., \& Martins, C. P. (2014). Archaeology, societies and environment in Africa. In Proceedings of the 16th UISPP World Congress, Burgos. Oxford: Archaeopress.

Oosterbeek, L., Martins, C. P., \& Domingos, Z. (2012). Ebo e a arte rupestre do Sudoeste de África. Tomar: CEIPHAR, série ARKEOS, 33, 139.

Pais Pinto, L. (1992). Arqueologia da Bacia Sedimentar de Benguela: A Idade da Pedra e do Ferro. LEBA - Estudos de pré-história e Arqueologia, 7, 203-220.

Pais Pinto, L. (1988). Le Musé National d'Archaeologie de Benguela (Angola): Bilan des premiers travaux, 19791987. Paris: CICIBA-Ministère de la Coopération et du Développement / Centre Culturel Français de Libreville.

Pereira, R. M. (2005). Conhecer para dominar: $O$ desenvolvimento do conhecimento antropológico na política colonial portuguesa em Moçambique, 1926-1959. $\mathrm{PhD}$ dissertation. Faculdade de Ciências Sociais e Humanas: Universidade Nova de Lisboa, Lisbon.
Phillipson, D. W. (1976). The prehistory of Eastern Zambia. Memoir 6. Nairobi: British Institute in Eastern Africa.

Pickford, M., Fernandes, T., \& Aço, S. (1990). New discoveries of primate-bearing fissure fillings in the "Planalto da Humpata", Huíla, Southern Angola. Compte Rendus Academie Sciences Paris, 310, 843-848.

Pickford, M., Mein, P., \& Senut, B. (1994). Fossiliferous Neogene karst fillings in Angola, Botswana and Namibia. South African Journal of Science, 90, 227-230.

Pickford, M., Mein, P., \& Senut, B. (1992). Primate bearing PlioPleistocene cave deposits of Humpata. Southern Angola. Human. Evolution, 7, 17-33.

Pinto, I. \& Coelho, A.G. (2014-2020). Apontamentos sobre as coleções arqueológicas de Angola. Projeto Georreferenciação das coleções históricas e científicas do IICT (2014-2020).

Pinto, I., \& Coelho, A. G. (2015). Redescobrindo estações arqueológicas à guarda do IICT. Africana Studia, 24, 161167.

Porto, N. (2009). Modos de objectificação da dominação colonial: o caso do Museu do Dundo, 1940-1970. Lisboa: Fundação Calouste Gulbenkian / Fundação para a Ciência e a Tecnologia.

Ramos, M. (1967). Relatório sucinto de uma missão de estudo no sudoeste de Angola: de 18 de Setembro 1966 a 17 de Março de 1967. Unpublished report from JIU - Junta de Investigações do Ultramar, Lisboa (IICT Archive).

Ramos, M. (1970). Algumas descobertas recentes no Sudoeste de Angola (nota prévia). Actas Das I Jornadas Arqueológicas, Lisboa, 1969, Vol. I (pp. 243-252). Lisboa: Associação dos Arqueólogos Portugueses.

Ramos, M. (1981). As escavações de Capangombe e o problema da MSA no SW de Angola. LEBA - Estudos de Pré-história e Arqueologia, 4, 29-35.

Ramos, M (1982). Le paléolithique du sud-ouest de l'Angola: vue d'ensemble. LEBA - Estudos de Pré-história e Arqueologia, $5,43-52$.

Ricardo, R. P., Marques, M. M., \& Ramos, M. F. (1981). Nota sobre o processo de formação dos solos ferralíticos da região do Hoque (província da Huíla - Angola). Boletim da Sociedade Geológica Portuguesa, 22, 337-347.

Rodrigues, M. C. (1992). In Memoriam: Miguel Ramos. $O$ Arqueólogo Português, 8(10), 9-16.

Rosina, P., Oosterbeek, L., Martins, C. P., \& Gomes, H. (2018). Dating and Raman spectroscopy of rock art paintings in Ebo Angola. Azania: Archaeological Research in Africa, 53(1), 83-97. https://doi.org/10.1080/0067270X.2018.1423758.

Rudner, J., \& Grattan-Bellew, P. (1964). Archaeological sites along the southern coast of Southwest Africa. South African Journal of Science, 60(3), 67-79.

Sadr, K. (2005). Un néolithique pour l'Afrique australe. Afrique \& Histoire, 2(4), 135-147.

Sadr, K. (2014). Radiocarbon dates, stone tools and the origin of herding on the west coast of South Africa. In Reports in African Archaeology, 6. Frankfurt am Main: Africa Magna Verlag.

Shaw, T., Sinclair, P., Andah, B., \& Okpoko, A. (Eds.). (1993). The archaeology of Africa. Food, metals and towns. London: Routledge.

Souindoula, S. (1992). Mbanza Soyo: Pesquisas arqueológicas. LEBA - Estudos de pré-história e Arqueologia, 7, 277-282. 
Telo, A. J. (1994). Economia e império no Portugal contemporâneo. Chamusca: Edições Cosmos.

Thornton, J. K., Ed. (2011). Firearms, diplomacy, and conquest in Angola: Cooperation and alliance in West Central Africa, 1491-1671. In W. E. Lee (Ed.) Empires and indigenes: Intercultural alliance, imperial expansion and warfare in the Early Modern world. New York: New York University Press.

Valdeyron, N., \& Domingos, S. (2009). Nouvelles données sur la Préhistoire récente angolaise: le gisement de Cabolombo à Benfica revisité. In Collectif De Méditerranée et d'ailleurs... Mélanges offerts à Jean Guilaine (pp. 737-749). Toulouse: Archives d'Écologie Préhistorique.

Valentim, C. M. B. (2016). A cartografia da Guiné Portuguesa 1945-1949. In M. G. Fernandes (Ed.) Porto, Atas do VI Simpósio Luso-Brasileiro de Cartografia Histórica, 4 a 7 de Novembro de 2015. Braga, Portugal, (pp. 40-47). Porto: Faculdade de Letras da Universidade do Porto

Vansina, J. (2004). How societies are born: Governance in West Central Africa before 1600. Charlottesville: University of Virginia Press.

Vilhena, J. (1955). A note on the Dundo Museum of the Companhia de Diamantes de Angola. Journal of the International Folk Music Council, 7, 41-43.

Volman, T. P. (1984). Early prehistory of South Africa. In R. G. Klein (Ed.), Southern African prehistory and palaeoenvironments. (pp. 169-220). Rotterdam: Balkema.

Publisher's Note Springer Nature remains neutral with regard to jurisdictional claims in published maps and institutional affiliations. 